\title{
Dimerelloid rhynchonellide brachiopods in the Lower Jurassic of the Engadine (Canton Graubünden, National Park, Switzerland)
}

\author{
Sulser, H ; Furrer, H
}

\begin{abstract}
New brachiopods (Dimerelloidea, Rhynchonellida) from Lower Jurassic (?lower Hettangian) hemipelagic sediments of the Swiss National Park in south-eastern Engadine are described: Sulcirostra doesseggeri sp. nov. and Carapezzia engadinensis sp. nov. Sulcirostra doesseggeri is externally similar to S. fuggeri (Frauscher 1883), a dubious species, that could not be included in a comparative study, because relevant samples no longer exist. A single specimen was tentatively assigned to Sulcirostra ?zitteli (Böse 1894) by comparison of its external morphology with S. zitteli from the type locality. The partly silicified brachiopods are associated with sponge spicules, radiolarians and crinoid ossicles. Macrofossils are rare: dictyid sponges, gastropods, bivalves, crustaceans, shark teeth and scales of an actinopterygian fish. The Lower Jurassic sediments (Alpisella beds, a basal member of the Allgäu Formation) preserving the brachiopods belong to the Ortler nappe (Upper Austroalpine nappes). The exact age of the Alpisella beds is not known, as index fossils are lacking. Their stratigraphic position above the Rhaetian Kössen Formation and below the ammonite-dated Trupchun beds suggests a very Early Jurassic, probably early Hettangian age for the new brachiopod fauna. The new species of Sulcirostra and Carapezzia are confined to a very small geographic area, a peculiarity also observed in other Early Jurassic dimerelloid brachiopods. These brachiopods presumably adapted to current-dominated submarine highs, where their shells could not accumulate, except when trapped in submarine cavities or re-deposited in submarine fans. Transport by turbidity currents is suggested for the Early Jurassic dimerelloids from the Engadine. Problems with the generic definition of Sulcirostra and the higher rank classification of Carapezzia are discussed.
\end{abstract}

DOI: https://doi.org/10.1007/s00015-008-1250-8

Posted at the Zurich Open Repository and Archive, University of Zurich

ZORA URL: https://doi.org/10.5167/uzh-9761

Journal Article

Published Version

Originally published at:

Sulser, H; Furrer, H (2008). Dimerelloid rhynchonellide brachiopods in the Lower Jurassic of the Engadine (Canton Graubünden, National Park, Switzerland). Swiss Journal of Geosciences, 101(1):203-222.

DOI: https://doi.org/10.1007/s00015-008-1250-8 


\title{
Dimerelloid rhynchonellide brachiopods in the Lower Jurassic of the Engadine (Canton Graubünden, National Park, Switzerland)
}

\author{
HeINZ Sulser \& HeInz FurRer*
}

Key words: brachiopoda, Sulcirostra, Carapezzia, new species, Lower Jurassic, Austroalpine

\begin{abstract}
New brachiopods (Dimerelloidea, Rhynchonellida) from Lower Jurassic (?lower Hettangian) hemipelagic sediments of the Swiss National Park in south-eastern Engadine are described: Sulcirostra doesseggeri sp. nov. and Carapezzia engadinensis sp. nov. Sulcirostra doesseggeri is externally similar to S. fuggeri (FrAUSCHER 1883), a dubious species, that could not be included in a comparative study, because relevant samples no longer exist. A single specimen was tentatively assigned to Sulcirostra ? zitteli (BösE 1894) by comparison of its external morphology with $S$. zitteli from the type locality. The partly silicified brachiopods are associated with sponge spicules, radiolarians and crinoid ossicles. Macrofossils are rare: dictyid sponges, gastropods, bivalves, crustaceans, shark teeth and scales of an actinopterygian fish. The Lower Jurassic sediments (Alpisella beds, a basal member of the Allgäu Formation) preserving the brachiopods belong to the Ortler nappe (Upper Austroalpine nappes). The exact age of the Alpisella beds is not known, as index fossils are lacking. Their stratigraphic position above the Rhaetian Kössen Formation and below the ammonite-dated Trupchun beds suggests a very Early Jurassic, probably early Hettangian age for the new brachiopod fauna. The new species of Sulcirostra and Carapezzia are confined to a very small geographic area, a peculiarity also observed in other Early Jurassic dimerelloid brachiopods. These brachiopods presumably adapted to current-dominated submarine highs, where their shells could not accumulate, except when trapped in submarine cavities or re-deposited in submarine fans. Transport by turbidity currents is suggested for the Early Jurassic dimerelloids from the Engadine. Problems with the generic definition of Sulcirostra and the higher rank classification of Carapezzia are discussed.
\end{abstract}

\section{ZUSAMMENFASSUNG}

Neue Brachiopoden (Dimerelloidea, Rhynchonellida) aus unterjurassischen hemipelagischen Sedimenten (?unteres Hettangian) des Schweizerischen Nationalparks im südöstlichen Engadin werden als Sulcirostra doesseggeri sp. nov. und Carapezzia engadinensis sp. nov. beschrieben. Sulcirostra doesseggeri ist äusserlich S. fuggeri (FrAUSCHER 1883) ähnlich, einer zweifelhaften Spezies, die nicht in eine vergleichende Untersuchung einbezogen werden konnte, weil kein relevantes Material mehr vorhanden ist. Ein einzelnes Exemplar wird als Sulcirostra ?zitteli (BöSE 1894) bezeichnet, im Vergleich mit der Aussenmorphologie von S. zitteli der Typuslokalität. Die teilweise silizifizierten Brachiopoden waren mit Schwammnadeln, Radiolarien und Crinoiden-Stielgliedern assoziiert. Makrofossilien sind selten: dictyide Schwammreste, Bivalven, Gastropoden, Krebse, Haifischzähne und Schuppen eines Knochenfisches. Die Brachiopoden führenden unterjurassischen Sedimente (Alpisella-Schichten an der Basis der Allgäu-Formation) gehören zur Ortler-Decke (oberostalpine Decken). Das exakte Alter der Alpisella-Schichten ist nicht genau bekannt, da Leitfossilien fehlen. Ihre stratigraphische Position über der rhätischen KössenFormation und unter den durch Ammoniten datierbaren Trupchun-Schichten weist auf ein frühjurassisches Alter (wahrscheinlich frühes Hettangian) der neuen Brachiopodenfauna hin. Die neuen Spezies von Sulcirostra und Carapezzia sind auf ein sehr kleines Gebiet beschränkt, eine Besonderheit, die auch bei anderen dimerelloiden Brachiopoden des Unteren Jura beobachtet wurde. Diese Brachiopoden waren vermutlich an strömungsdominierte submarine Hochzonen angepasst, wo ihre Schalen nur dann akkumulieren konnten, wenn sie in submarinen Spalten liegen blieben oder auf submarine Schuttfächer umgelagert wurden. Ein Transport durch Trübeströme ist bei den aus dem Engadin beschriebenen frühjurassischen Dimerelloiden angezeigt. Probleme der generischen Definition von Sulcirostra und die supragenerische Klassifikation von Carapezzia werden diskutiert.

\section{Introduction}

The dimerelloids, a superfamily within the rhynchonellides, form a very distinctive group of the Brachiopoda. Early Jurassic members have variable external appearances, often unspec- tacular, but marked in their conspicuous internal features. They occur in the calcareous deposits of the Alpine-Dinaride belt (Austria, Lombardia, Dalmatia), in the Appenines (Umbria), Sicily, Bakony (Hungary), and in the Rif and Numidian moun-

Paläontologisches Institut und Museum der Universität Zürich, Karl Schmid-Strasse 4, CH-8006 Zürich, Switzerland.

*Corresponding author: Heinz Furrer. E-mail: heinz.furrer@pim.uzh.ch 
tains of North Africa (Morocco, Algeria). An overview of their geographical distribution was given by Dubar (1938). Single occurrences were reported in Turkey (Ager et al. 1978) and possibly in the Crimea (Borisjak 1909).

Until now only a single species of an Early Jurassic dimerelloid, Sulcirostra alpina (PARONA), from the Broccatello limestone of Arzo in the Southern Alps of Switzerland was known; it was recently revised by Sulser and Furrer (2005). This species, believed to be strictly endemic, was also located in the Eastern Alps of the Engadine valley (Canton Graubünden). As in the type locality in Arzo, the Engadine specimens of Sulcirostra alpina were found concentrated in a monospecific shell bed in a re-sedimented block. Along with several clasts of crinoidal limestone (Hierlatz limestone), one single block of "Rhynchonellina limestone" was found in a thick megabreccia (Alv breccia) at the base of the hemipelagic Allgäu Formation (Furrer 1993).

$2.5 \mathrm{~km}$ southeast, but still on the same western crest of Piz Chaschauna, additional dimerelloid brachiopods occur in dark grey limestone-marl-alternations of the basal AllgäuFormation (Alpisella beds, Dössegger et al. 1982). The brachiopods were first discovered by Zoeppritz (1906: 193) and noted in his text as "Rhynchonellina Fuggeri", "Rhynchonella sp." and "Terebratula cf. Gerstenensis" from the upper Val Chaschauna. He found the partly silicified brachiopods in the "western foothills of Punta Casana". Another site with dimerelloid brachiopods was discovered by N. Sieber and R. Trümpy in 1964 (Sieber 1965) on the southern flank of Val Trupchun (scree in the eastern part of Ils Fouruns, south of locality P. 2321) and R. Dössegger on the crest (west of locality P. 2857) during geological mapping in 1975. More material from several localities was collected by H. Furrer in 1979 and reported as Rhynchonellina suessi BöSE and Sulcirostra fuggeri (FRAUSCHER) (Furrer 1993: 80). These brachiopods are described in detail below.

\section{Geology and stratigraphy (H. Furrer)}

The new brachiopod material was found WNW of Piz Chaschauna, on the steep crest between the Trupchun and Chaschauna valleys, just at the border of the Swiss National Park in the upper Engadine valley, Canton Graubünden (south eastern Switzerland) (Fig. 1). The Lower Jurassic sediments belong to the "Engadine Dolomites", and are part of the upper Austroalpine nappes, forming a complex of highly allochthonous units of basement rocks and their Mesozoic sedimentary cover (Trümpy 1980). The mountains of this area on the south eastern side of the Engadine valley consist of thick Middle and Upper Triassic platform carbonates, mainly dolomites, overlain by hemipelagic limestone-marl-alternations of Early Jurassic to Early Cretaceous age. The Mesozoic sediments are partly still in contact with the basement, but have also been partly sheared off. A detailed geological map was published by Dössegger (1987), followed by an explanatory text (Trümpy et al. 1997). Stratigraphic sections were compiled by Dösseg- ger et al. (1982) and Furrer (1985, 1993). Triassic carbonates (especially dolomites) are dominant and younger sediments have only been preserved in the Ortler nappe. The Ortler sediments are, for the most part, tectonically detached from their Campo substratum (except for small autochthonous remnants on Alpe Trela and in Val Chaschauna), and attributed to the Central or Upper Austroalpine nappes (Trümpy 1980, Froitzheim et al. 1994).

The Chaschauna and Trupchun valleys expose a complete section across the western Ortler nappe, comprising, from south to north, basement gneiss, Permian and Triassic continental detritic sediments, Middle Triassic to Upper Triassic shallow marine carbonates and Lower Jurassic hemipelagic sediments (Fig. 2). Upper Jurassic and Lower Cretaceous pelagic sediments occur in a narrow, overturned syncline just below the Quattervals overthrust (Caron et al.1982). Along the steep crest from Piz Chaschauna in a WNW direction until locality P. 2452.8, various spectacular exposures display Jurassic and Alpine normal faults (Froitzheim 1988). The Triassic sediments are shown to be greatly reduced in thickness by normal faults and superficial erosion during the Early Jurassic rifting phase (Eberli 1987, 1988; Froitzheim \& Eberli 1990). Early Jurassic erosion is documented by chaotic megabreccias overlying the basal beds of the Kössen Formation or directly deposited on the fractured Hauptdolomite (Dössegger et al. 1982; Furrer 1985, 1993). Characteristic re-sedimented components are coral-brachiopod limestones, oolitic limestones and lumachelles from the middle and upper Kössen Formation (Schesaplana and Mitgel Member). On the slope south-east of locality P. 2452.8, the Hauptdolomite is reduced in thickness and superficially cut by a system of fissures filled by white dolomitic cement and red dolomitic marlstone. Breccias and red echinoderm limestone form a later fissure filling (Alv breccia) (Fig. 3: section A). Sulcirostra alpina has been found in a clast of the overlying megabreccia (Sulser \& Furrer 2005). Normal faults have displaced the $500 \mathrm{~m}$ thick Hauptdolomite (Norian) and the overlying marl and limestone alternation of the Kössen Formation (Norian-Rhaetian), interpreted by Froitzheim (1988) as Early Jurassic and Tertiary Alpine normal faults, resulting in a series of tilted blocks.

Stratigraphic sections of the Ortler nappe along the steep crest from Piz Chaschauna in a WNW direction as far as locality P. 2452.8, document rapid facies changes in the Lower Jurassic sediments and variable contacts to the underlying Upper Triassic carbonates (Fig. 3). The dimerelloid brachiopods were found north-west, west and south-west of locality P. 2857, a peak about $1 \mathrm{~km}$ north-west of Piz Chaschauna. Most of the material was collected from scree in Val Trupchun (in the eastern glacial cirque of Ils Fouruns in the Swiss National Park; not accessible without a special permit available from the Park service). Only a few specimens were discovered in section $\mathrm{C}$ and some patchy exposures approaching the crest at an altitude of 2700 to $2800 \mathrm{~m}$ above sea level. An isolated exposure with dimerelloid brachiopods was also located in the same stratigraphic position just on the crest. This is the source of the brachiopods found in

204 H. Sulser \& H. Furrer 


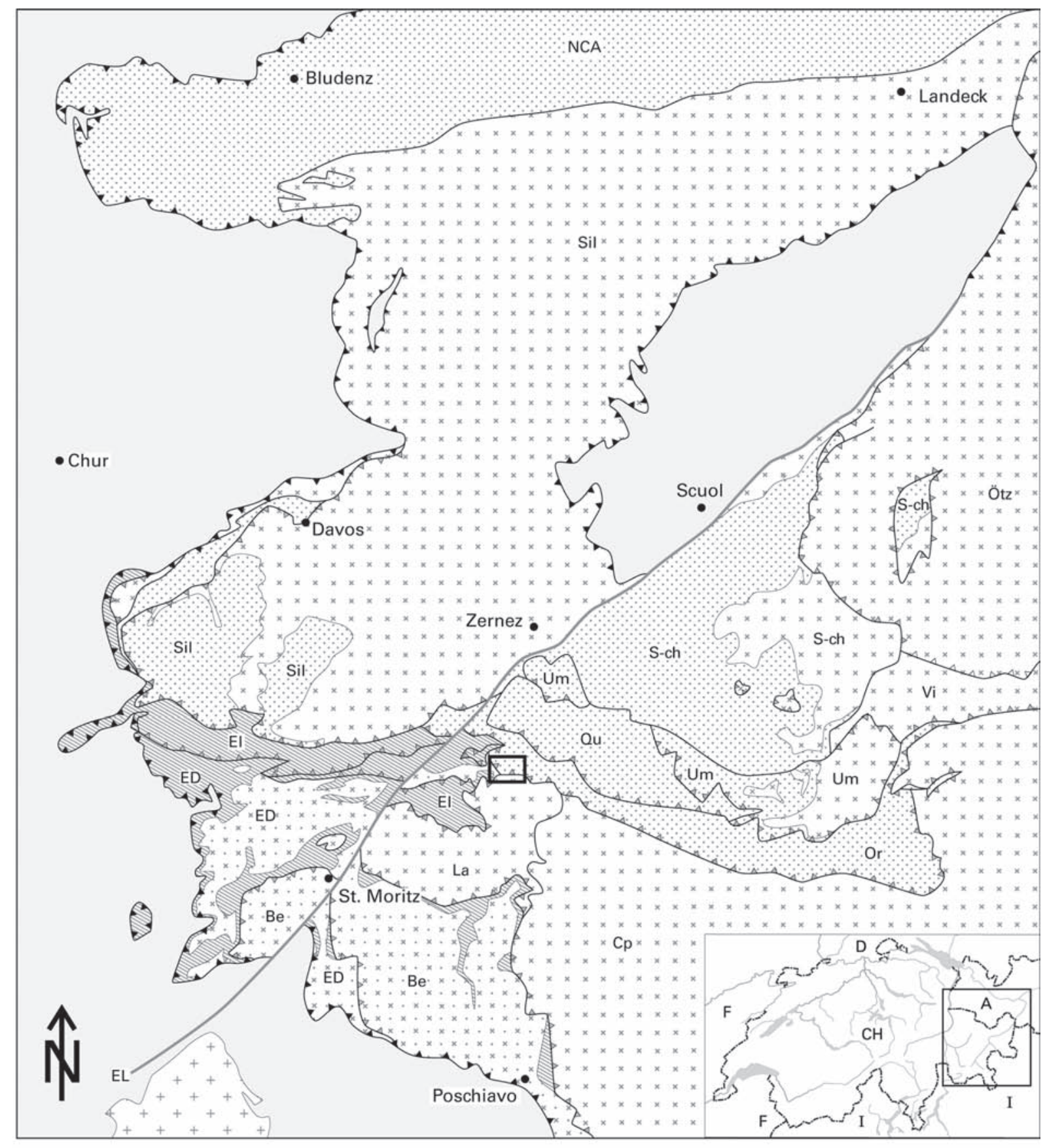

0

10

20

30

40

$50 \mathrm{~km}$

Detailed map (see next figure)

\section{Upper Austroalpine nappes}

Mesozoic sediments

\begin{tabular}{|llll}
$x$ & $x$ & $x$ & $x$ \\
$x$ & $x$ & $x$ & $x$
\end{tabular}$\quad$ Basement

\section{Lower Austroalpine nappes}

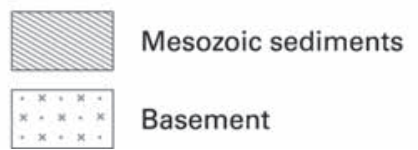

Penninic nappes:

Bergell intrusion

Fig. 1. Simplified geological map of the Austroalpine nappes in Canton Graubünden (modified after BWG 2005:Tektonische Karte der Schweiz $1: 500$ '000). Be: Bernina nappe; Cp: Campo nappe; ED: Err complex; El: Ela nappe; EL: Engadine Line; La: Languard nappe; NCA: Northern Calcareous Alps (Lechtal nappe); Or: Ortler nappe; Ötz: Ötztal nappe; Qu: Quattervals nappe: S-ch: S-charl nappe; Sil: Silvretta nappe; Vi: Vinschgau mylonite; Um: Umbrail-Chavalatsch slices. 

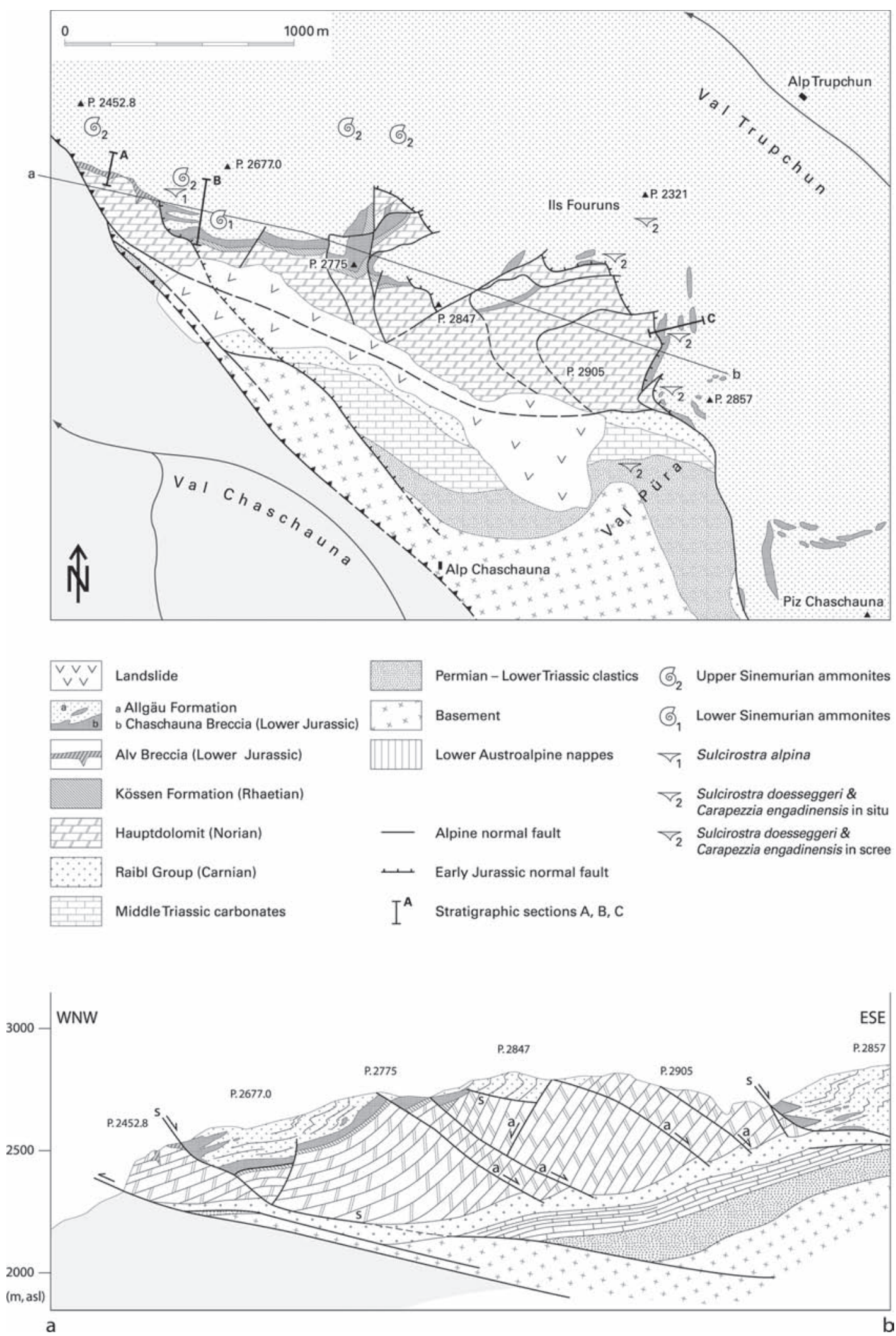

Fig. 2. Geological map of the studied area, southeast of S-chanf in the Engadine valley (above) and geological section a-b (below; modified after Froitzheim 1988). Most of the fossils were collected from scree (in the eastern glacial cirque of Ils Fouruns) and from the stratigraphic section C in Val Trupchun (Swiss National Park; not accessible without a special permit available from the Park service). 


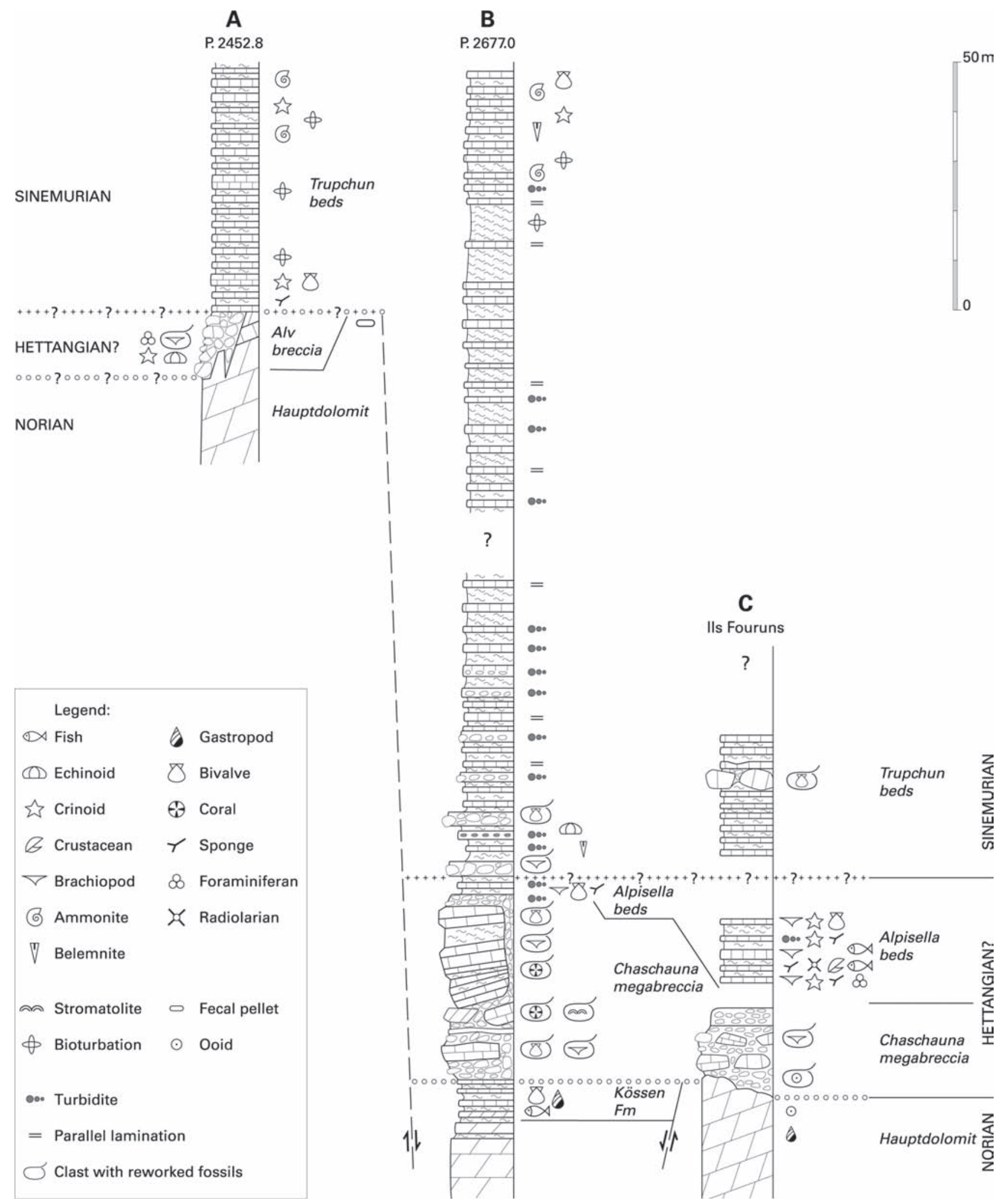

Fig. 3. Stratigraphic sections of the Upper Triassic and Lower Jurassic sediments along the steep crest between Val Trupchun and Val Chaschauna (Ortler nappe, Austroalpine). The dimerelloid brachiopod Sulcirostra alpina was found in a re-sedimented block in the Alv breccia of section A. The new dimerelloid brachiopods Sulcirostra doesseggeri sp. nov. and Carapezzia engadinensis sp. nov. have been found only in the Alpisella beds of section C. For the position of sections A-C see Figure 2. 


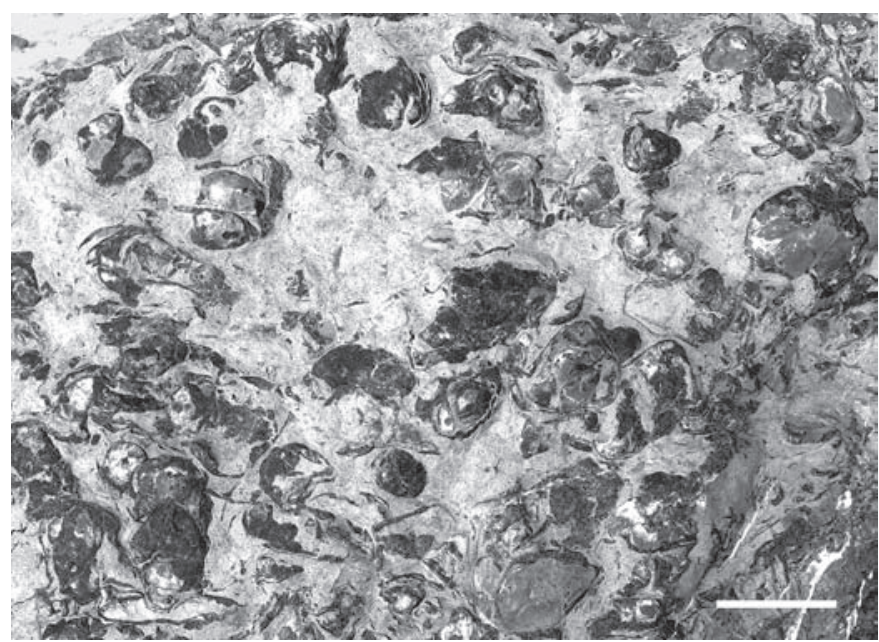

Fig. 4. Dimerelloid brachiopods (Carapezzia engadinensis sp. nov.) on the surface of a monospecific shell bed of the Alpisella beds from Val Püra. Scale bar: $5 \mathrm{~cm}$.

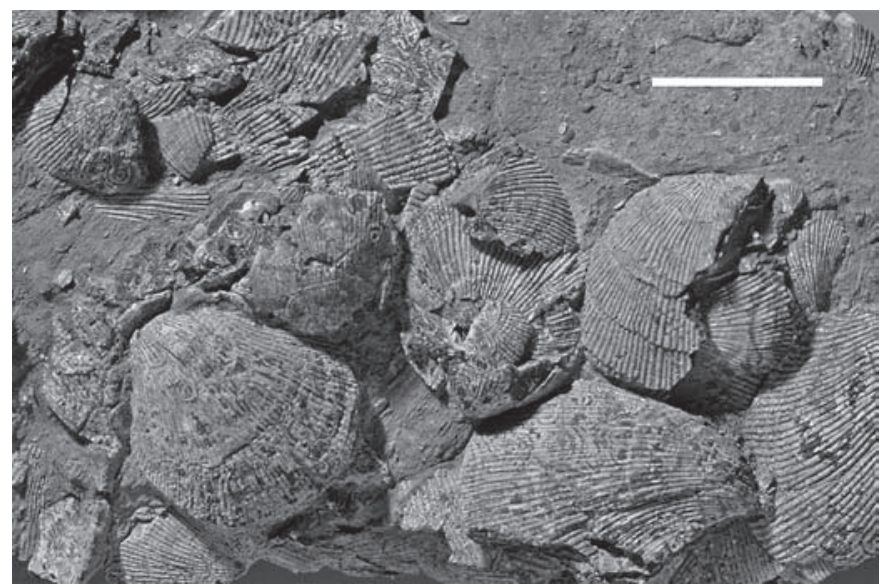

Fig. 5. Partly silicified dimerelloid brachiopods (Sulcirostra doesseggeri sp. nov.) on the surface of a monospecific shell bed of the Alpisella beds from Ils Fouruns (PIMUZ 26 670). Scale bar: $1 \mathrm{~cm}$.

the scree in the small valley (Val Püra) on the southern slope, $1.5 \mathrm{~km}$ north-east of Alp Chaschauna.

A discontinuous section in the uppermost part of the eastern Ils Fouruns, north-west of locality P. 2857 (Fig. 3: section C) shows that the 10-15 m thick fossiliferous Alpisella beds with the dimerelloid brachiopods are intercalated between a basal megabreccia and an alternation of dark grey limestones and marls typical of the Allgäu Formation (Trupchun beds). The megabreccia directly covers the upper Hauptdolomite Formation with an angular unconformity. Large olistoliths are also enclosed in the younger Trupchun beds. A similar section, but without dimerelloid brachiopods, is documented south-east of locality P. 2677.0 (Fig. 3: section B), where a basal megabreccia is overlain by thinning and fining upwards breccias, intercalated with limestone and marls of the Trupchun Member.

The exact age of the Alpisella beds with the dimerelloid brachiopods is not known, due to the lack of ammonites or other index fossils. At the base of the overlying Trupchun beds, one specimen of an Early Sinemurian ammonite has been found (Arnioceras sp.). Higher up, a succession of marly limestones and marlstones rich in ammonites of Late Sinemurian to Earliest Pliensbachian age (Asteroceras sp., Echioceras sp., Paltechioceras sp., Uptonia sp.) is widespread throughout the entire Ortler nappe (Furrer 1993). In the central Ortler nappe near Livigno (Il Motto, La Paré) the spiculitic Alpisella beds are overlain by a well-bedded limestone (Naira limestone) dated by late Hettangian ammonites (Schlotheimia sp., Furrer 1985, 1993). The most accurately dated section lies in the Alpisella valley north of Monte Torraccia, where an early Hettangian Psiloceras naumanni was found at the top of the Alpisella beds, and a late Hettangian Schlotheimia montana and Angulaticeras cf. marmoreum were found in the lower part of the Trupchun beds (Conti et al. 1994). In all these sections, dimerelloid brachiopods are absent. However, the stratigraphic position of the Alpisella beds below the upper Hettangian Naira limestone and the upper Hettangian to Sinemurian Trupchun beds suggests a very Early Jurassic, probably early Hettangian age for the new brachiopod fauna.

\section{Fossil content and preservation (H. Furrer)}

The dimerelloid brachiopods are usually found as monospecific shell beds in dark grey spiculitic limestones, and spiculitic marly limestones. The best preserved articulated specimens are matrix-supported in a spiculitic marly limestone (sparse biomicrite or floatstone), conjoined and partly silicified (Fig. 4). Other beds are component-supported spiculitic limestones (packed biomicrite or rudstone, Fig. 5). These densely packed shell beds often include isolated and fragmented brachiopod valves. Some conjoined specimens are only partly filled with sediment at the bottom whereas the upper part is filled with calcite cement (geopetal fabric). Dolomite and lime mud pebbles, crinoid ossicles and well sorted sponge spicules in these brachiopod shell beds suggest transport and re-sedimentation by currents, but graded bedding with fining upward sequences is rare (Fig. 6).

The shell beds are interbedded with finely laminated calcareous spiculites, splitting as dark slates. The planar lamination suggests deposition as fine grained turbidites, without any signs of bioturbation. Besides the dominant sponge spicules (mainly monaxons), radiolarians and small crinoid ossicles, only a few macrofossils have been found: fragmentary skeletons of dictyid sponges, some bivalves (Oxytoma sp., Chlamys sp.), a gastropod, a fragmentary small ammonite (Waehneroceras? sp.), ostracods and a few articulated specimens of decapod crustaceans, including a nearly complete specimen of Coleia viallii PINNA 1969, some isolated shark teeth (Sphenodus sp.), and disarticulated scales and a vertebra of an actinopterygian fish. Besides the di-

208 H. Sulser \& H. Furrer 


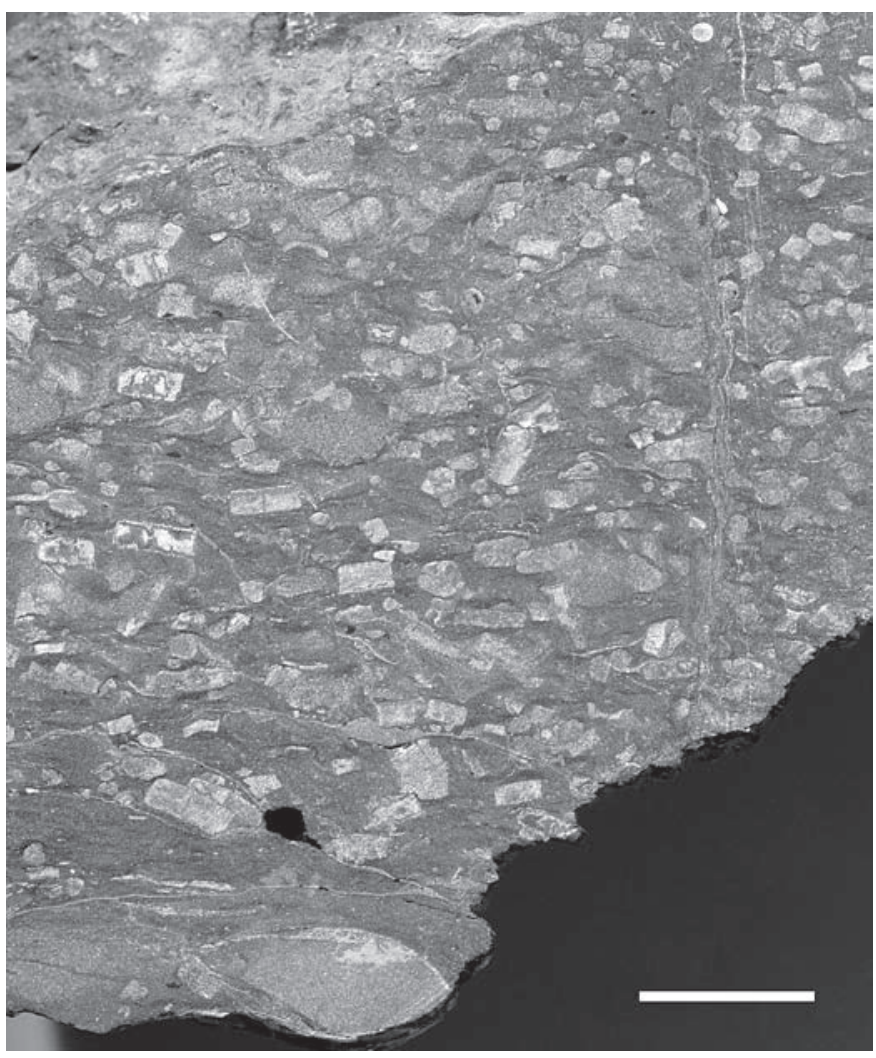

Fig. 6. Section of a bioclastic limestone with crinoid ossicles and sponge spicules. Note the section of Sulcirostra doesseggeri sp. nov. at the base and graded bedding in the upper part (Alpisella beds from Ils Fouruns) (PIMUZ 26 671). Scale bar: $1 \mathrm{~cm}$.

merelloid brachiopods one specimen of a probably wellerelloid rhynchonellide (Calcirhynchia? sp.) has been found.

\section{Material and methods}

The fossils were collected by R. Trümpy in 1964, R. Dössegger in 1975 and H. Furrer in 1979, 2006, and are stored in the collection of the Palaeontological Institute and Museum of Zürich University (PIMUZ). The calcitic shells of the bivalves and brachiopods are partly silicified, but only a few specimens could be prepared by acetic acid. Mechanical preparation of the umbones allowed a more precise description of the apical area and the pedicle opening.

Several attempts to investigate parts of the internal structures of the brachiopods, like the crura, septum or articulation by acid treatment, failed. A series of transverse sections were obtained by conventional, step-wise grinding in regular intervals of $0.2 \mathrm{~mm}$. Selected sections displaying characteristic and diagnostic features were documented by peeling on acetate foils or photographically, enlarged 2- to 3-fold and copied by drawing. Numbers indicate the distance from the apex to the plane of the section. A longitudinal section par- allel to the median line of an intact conjoined shell yielded additional information about internal structural details. The transverse serial sections are presented with the ventral valve above for ready comparisons with the majority of the published sections of Mesozoic rhynchonellides. Figures showing the anterior view of brachiopods are orientated with the dorsal valve above.

The specimens of Sulcirostra zitteli from the type locality Hohenschwangau (Figs. 12a-d) are deposited at the Bayerische Staatssammlung, Munich (inventory numbers AS). The specimen of Carapezzia geyeri used for serial sections (Fig. 21) was a non-figured syntype of the Geologische Bundesanstalt, Vienna.

\section{Systematic palaeontology (H. Sulser)}

$\begin{array}{ll}\text { Phylum } & \text { Brachiopoda DUMÉRIL } 1806 \\ \text { Subphylum } & \text { Rhynchonelliformea WILLIAMS et al. } 1996 \\ \text { Class } & \text { Rhynchonellata WILLIAMS et al. 1996 } \\ \text { Order } & \text { Rhynchonellida KUHN 1949 } \\ \text { Superfamily } & \text { Dimerelloidea BUCKMAN 1918 } \\ \text { Family } & \text { Dimerellidae BUCKMAN } 1918 \\ \text { Subfamily } & \text { Rhynchonellininae AGER 1959 } \\ \text { Genus } & \text { Sulcirostra COOPER \& MUIR-WOOD 1951, nom. } \\ & \text { nov. for preoccupied Rhynchonellopsis DE GRE- } \\ & \text { GORIO 1930. Type species: Rhynchonellina seg- } \\ & \text { uenzae (originally spelt sequenzae) GEMMEL- } \\ & \text { LARO 1871. }\end{array}$

\section{Sulcirostra doesseggeri sp. nov.}

(Figs. 7-11)

1906 “Rhynchonellina Fuggeri” - Zoeppritz: 193

1993 Sulcirostra fuggeri (FRAUSCHER) - Furrer: 80

Derivation of name. - doesseggeri, in memory to the geologist Dr. Rudolf Dössegger (1944-2003), who introduced one of the authors (H. Furrer) to the geology of the Engadine Dolomites and called his attention to the fossil locality Ils Fouruns.

Type locality. - Ils Fouruns (eastern glacial cirque, coordinates on Swiss topographic maps: 801.300/162.900), Swiss National Park near S-chanf, Canton Graubünden, Switzerland. Alpisella beds of the Allgäu Formation (?lower Hettangian); Ortler nappe (Austroalpine nappes).

Holotype. - PIMUZ 26650 (Figs. 7a, b). Dimensions: $24.1 \mathrm{~mm}$ long, $23.8 \mathrm{~mm}$ wide, $8.6 \mathrm{~mm}$ thick.

Paratypes. - PIMUZ 26676 (Fig. 7c), PIMUZ 26677 (Fig. 7d). Occurrence. - Type locality.

Diagnosis. - Biconvex, rectimarginate, costellate shell; hinge line almost straight; umbo curved, interarea high; closely parallel, long crura of the ensiform type.

Description. - For the morphological information a small number of isolated specimens were used. Additional specimens attached to the substrate have exposed dorsal or ventral valves (Table 1). 

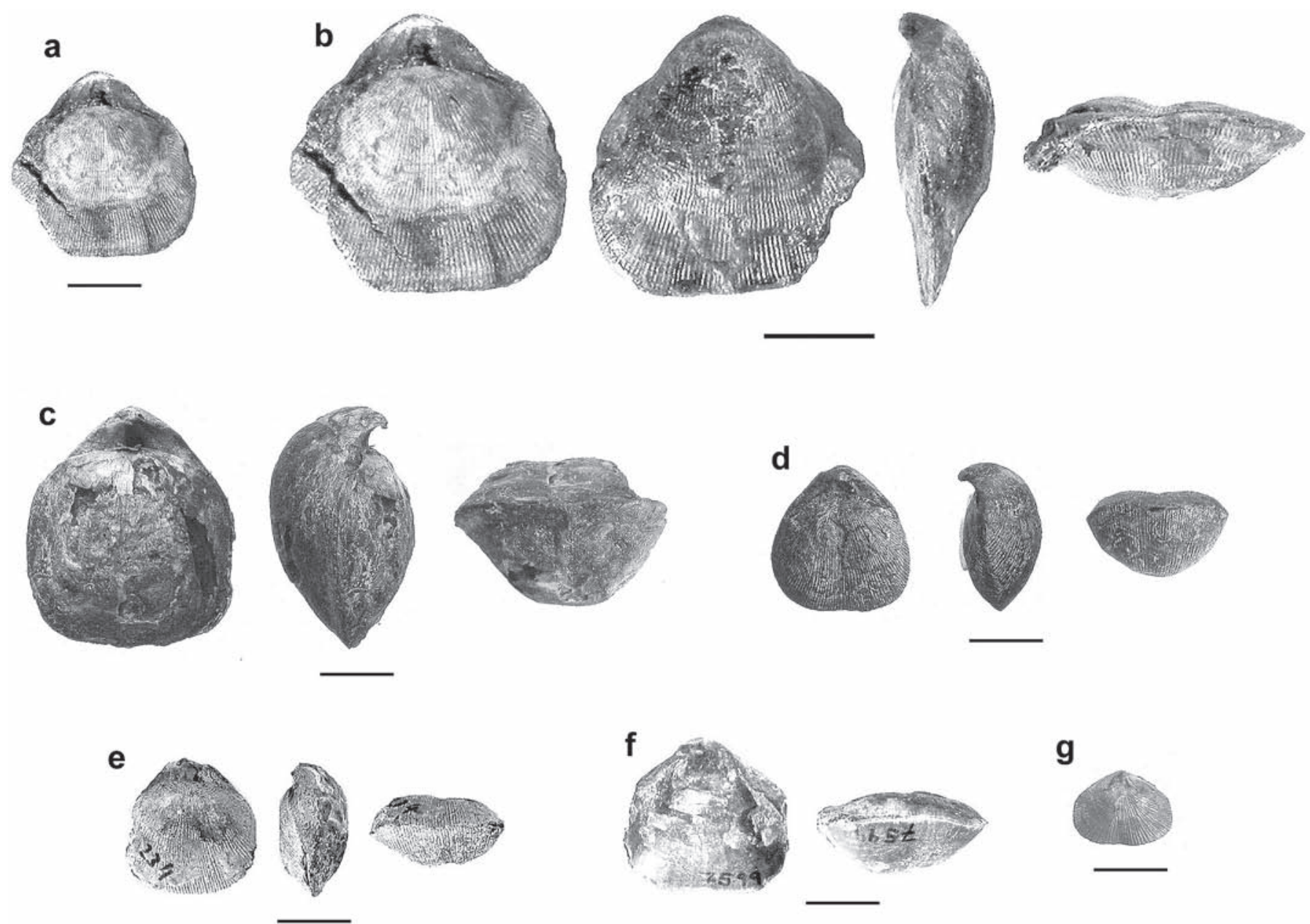

Fig. 7. Sulcirostra doesseggeri sp. nov. from Ils Fouruns (?lower Hettangian, Canton Graubünden, Switzerland). a) Dorsal view of holotype, natural size. b) Different views of enlarged holotype, showing a rounded-subpentagonal outline, a relatively flat profile, and an almost rectimarginate anterior commissure, from left: dorsal, ventral, lateral, and anterior views (PIMUZ 26 650). c, d) Paratypes, natural sizes, showing a quite inflated dorsal valve and a pointed umbo, from left: dorsal, lateral, and anterior view (c) (PIMUZ 26 676), a rounded-trigonal outline, from left: dorsal, lateral, and anterior view (d) (PIMUZ 26677 ). e-g) different specimens, natural size, showing an almost circular outline, and a very weak sulcate anterior commissure, from left: dorsal, lateral, and anterior view (e) (PIMUZ 26 651), a distinct pentagonal outline and a very weak uniplicate anterior commissure, from left: dorsal and anterior view (f) (PIMUZ 26 652), a small dorsal valve with width exceeding length (g) (PIMUZ 26 678). Scale bars: $1 \mathrm{~cm}$.

External morphology (Figs. 7-9).Average shell length of $24 \mathrm{~mm}$, width about equal to length, juveniles often somewhat wider than long (Figs. 7g, 9), thickness about half the length (Table 1). Profile biconvex, but dorsal valve usually flattened; maximum thickness in posterior third of the shell; the lateral margin is sharp, the lateral commissure straight, and anteriorly slightly curved. Hinge line wide, gently curved or almost straight. Ventral outline subpentagonal, tending to become more pronounced pentagonal or rounded-oval. Both valves covered with numerous dense, frequently branching or intercalated ribs (20-26 on $10 \mathrm{~mm}$ of width, measured at anterior margin, see Figs. 8c-e). Concentric growth lines irregular, weak or scarcely detectable. Dorsal valve with small, shallow sulcus, extending from hinge line to anterior margin while slightly broadening. Ventral valve lacking sulcus or fold. Anterior commissure sul- cate or almost rectimarginate. Umbo pointed, suberect to erect, with sharp areal ridges (Fig. 7a); interarea high, concave. Delthyrium open, triangular, with traces of flanking deltidial plates (Fig. 8b). Apical angle $90-100^{\circ}$.

Internal morphology (Figs. 10, 11). Ventral valve: dental plates weak, apically fused to the lateral wall, anteriorly subparallel disappearing before the development of the teeth. Hinge teeth inserted obliquely. Dorsal valve: hinge plate posteriorly forming a massive, characteristically shaped compact cardinalium, involving median septum before dividing and forming closely parallel, long crura; the crura extend beyond midvalve, bending strongly towards the ventral valve, and ultimately almost reach the floor of ventral valve. Median septum flat, quite persistent. 


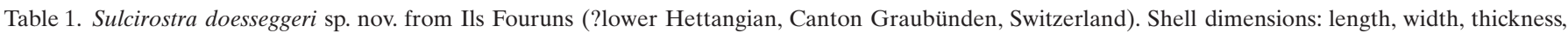

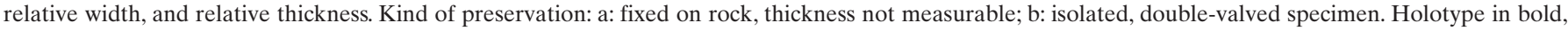
paratypes in italics.

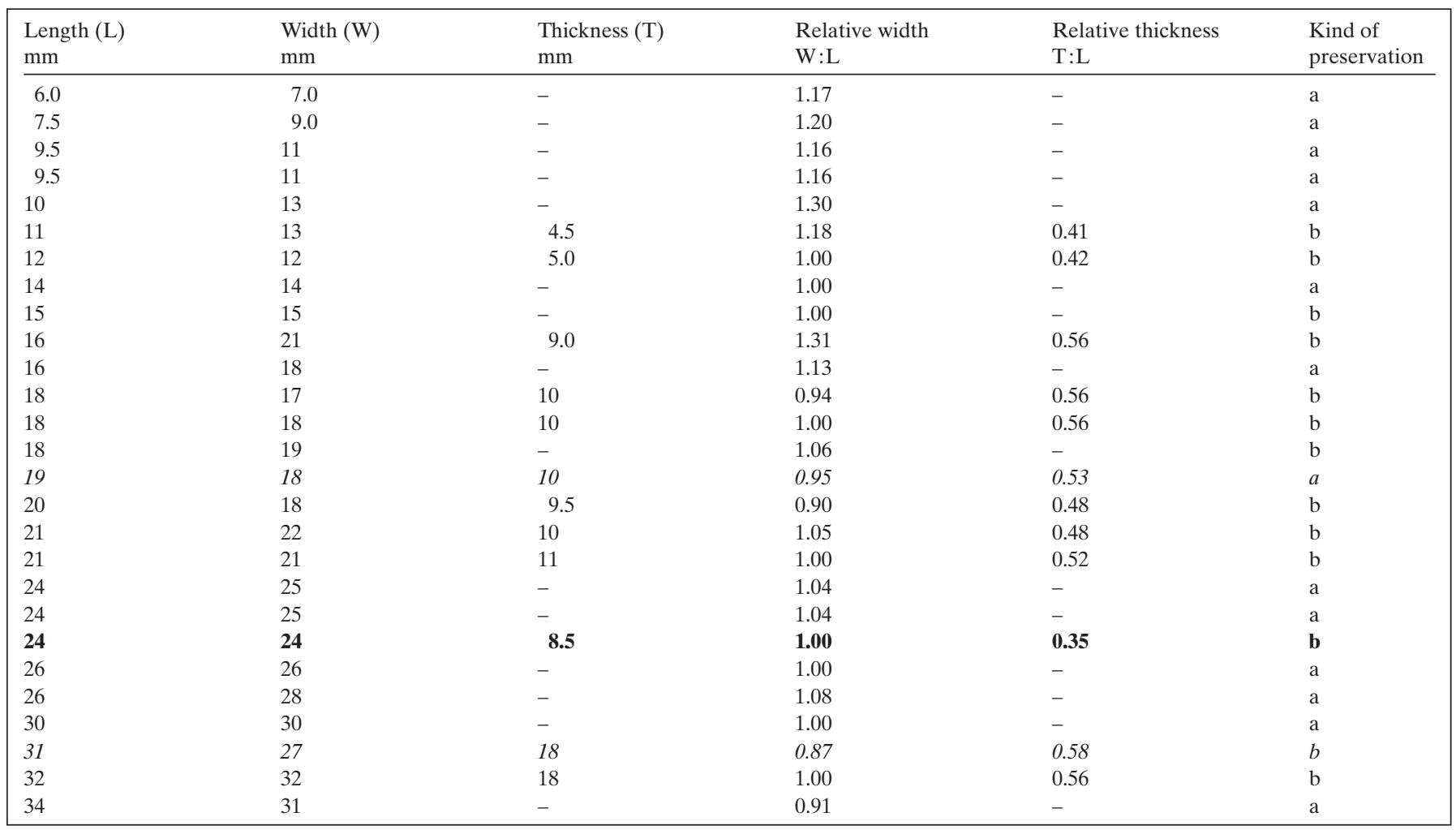

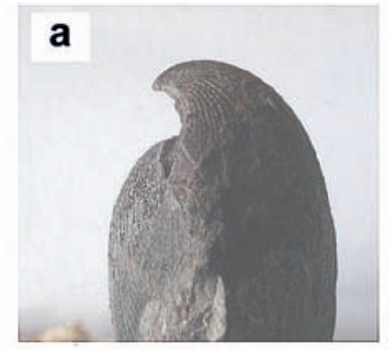

C

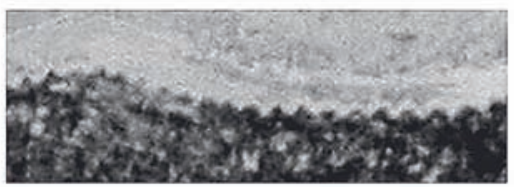

d

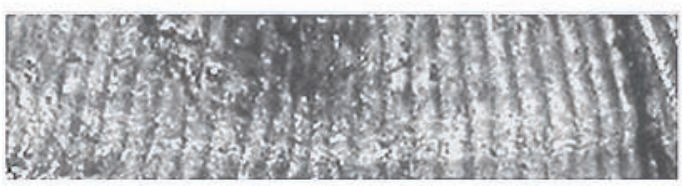

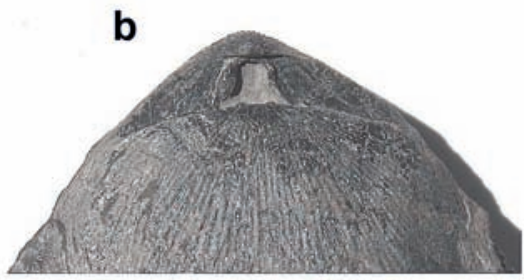

e

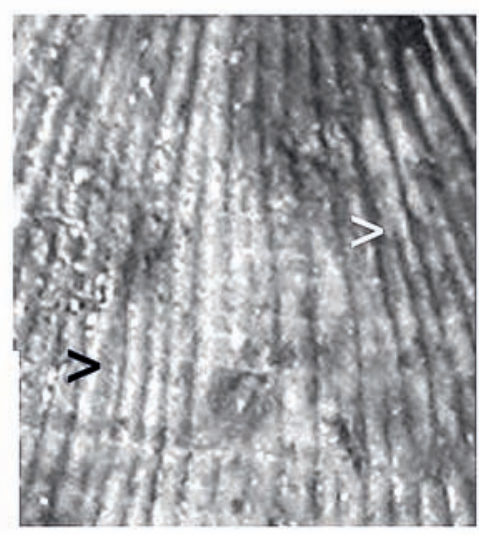

Fig. 8. Sulcirostra doesseggeri sp. nov. from Ils Fouruns (?lower Hettangian, Canton Graubünden, Switzerland). a, b) Specimen with prepared posterior region, showing the markedly incurved beak (a); the open delthyrium with traces of deltidial plates and the weekly curved hinge line (b) (PIMUZ 26 653). c-e: Details of costae on dorsal valve: profiles in transverse section in about half-shell length (c) (PIMUZ 26 655); density (d), dichotomizing (white arrow head), and intercalating (black arrow head) (e) (PIMUZ 26 650). Scale bars: $0.5 \mathrm{~cm}(\mathrm{c}-\mathrm{e}) ; 1 \mathrm{~cm}(\mathrm{a}, \mathrm{b})$. 


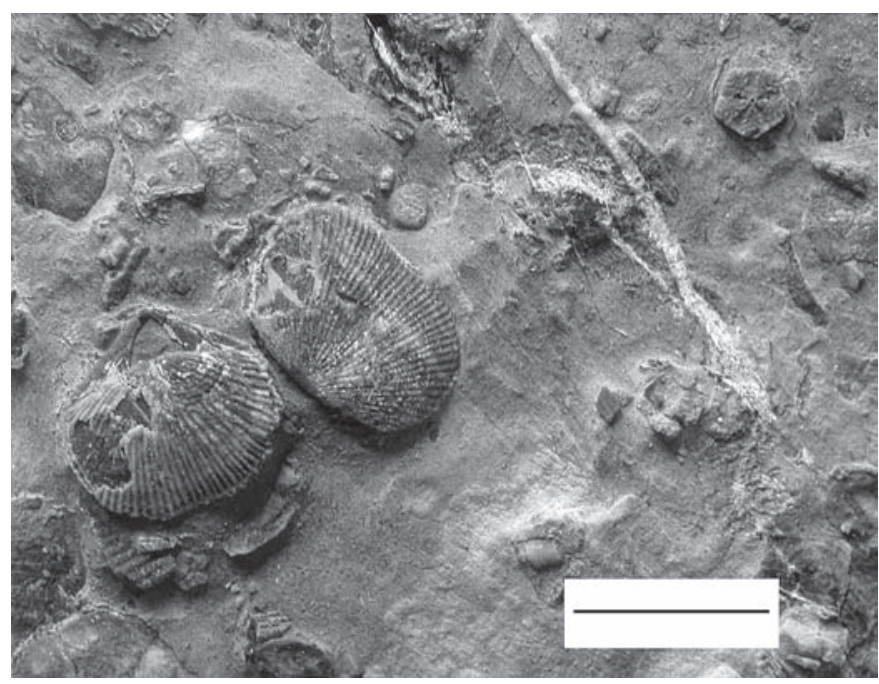

Fig. 9. Sulcirostra doesseggeri sp. nov. from Ils Fouruns (?lower Hettangian, Canton Graubünden, Switzerland). Two small specimens attached to substrate. Left: dorsal valve with large triangular delthyrium (PIMUZ 26 654). Above right: isolated internodal of Isocrinoidea gen. et sp. indet. Scale bar: $1 \mathrm{~cm}$.

Discussion. - Supraspecific classification. The most important criterion for the supraspecific ranking of the new species doesseggeri is the exceptionally long, curved, closely parallel crura of the ensiform type. That suggests a placement in the suberfamily Dimerelloidea, and more precisely in the family Dimerellidae. In this family actually four genera are united: Dimerella ZITTEL 1870, the type genus, is a rare and little known form of the Late Triassic (Norian). It is characterized by an extraordinarily high dorsal median septum which forms a partition across the shell. Cooperrhynchia SANDY \& CAMPBELL 1994 from the Upper Jurassic (Tithonian) shows a shell of subtrigonal outline with shallow sulci on both valves. Both, Dimerella and Cooperrhynchia can be disregarded. Possible generic assignments for the species doesseggeri are, however, Rhynchonellina GEMMELLARO 1871 and Sulcirostra COOPER \& MUIR-WOOD 1951. This is discussed in more detail.

Rhynchonellina originally comprised about 20 species with considerable morphological variation (Böse 1894). The shell ornament ranges from smooth or feebly capillate to costellate and costate, and the pedicle foramen is formed by a delthyrium with more or less rudimentary deltidial plates. The erection of Sulcirostra (formerly Rhynchonellopsis) enabled a simple subdivision of external morphology: smooth forms were included in Rhynchonellina s.s. and ribbed forms in Sulcirostra. Ager (1959) made serial sections of the Austrian Rhynchonellina juvavica BITTNER 1890, on the assumption that this species was a subjective synonym of the Sicilian Rhynchonellina seguenzae, the type species of Sulcirostra. In the first edition of the Treatise (Ager 1965b: H602, Fig. 483, 2) Sulcirostra was defined: "like Rhynchonellina but costate; no septalium; very short median septum and lateral septa supporting massive hinge plates". Subsequent authors questioned this synonymy. In the revised
Treatise, Manceñido et al. (2002: vol. 4, p. 1237, Fig. 842, 4d-i) included sections of a species from northern Italy, Rhynchonellina paronai BösE 1894, which Cicardi \& Gaetani (1974) had assigned to Sulcirostra. Obviously, the cardinal region in the sections of Rhynchonellina paronai is different from those produced by Ager (1959). They show certain affinities to Rhynchonellina when compared to its type species, R. suessi GEMMELLARO 1871. In particular they show no trace of what might be taken for "septa supporting hinge plates" (pers. comm. by M.O. Manceñido). The species described here, doesseggeri, shows a further difference in the proximal part of the internal structure. The cardinalium is a compact, undivided structure without septalium and lateral open cavities. A dubious species, alpina, was described by Cicardi \& Gaetani (1974) and assigned by these authors and Sandy \& Campbell (1994) to Rhynchonellina and by Sulser \& Furrer (2005) to Sulcirostra. Long crura are supported by septa, originating at the shell wall, and hinge plates cannot be detected. They approach the septiform type.

At the time being Sulcirostra is a kind of "patchwork genus". Transverse serial sections based on topotypes of S. seguenzae are unknown, and several species ascribed to this genus differ interiorly. In this paper we used Sulcirostra in a broad sense. We consider the type of crura (ensiform) and the costation/costellation of the shell as the diagnostic generic characters and regard the cardinal region a species-dependent character. Under this condition we do not hesitate to combine doesseggeri with Sulcirostra. With the progress of research, however, the need for a new genus (or even genera) is an option faced for future work.

Comparison at the species level. Sulcirostra doesseggeri, constituting the majority of the Engadine brachiopod fauna, is of the finely ribbed (costellate) shell type. It shares a number of common features of external morphology with other potential Sulcirostra species of still unknown internal structures. Comparable characters concern the general shape, similar size, the relations between length, width and thickness, similar profile and outline, the umbo region, a sulcate shell, an open delthyrium, and a more or less straight hinge line. Species which belong to this costellate group are: S.? hofmanni (BÖCKH 1874), fuggeri (FRAUSCHER 1883), brusinai (EICHENBAUM 1883), paronai (BÖSE 1894), zitteli (BÖSE 1894), and gemmellaroi (BITTNER 1895). Other species of Sulcirostra? differ either by having coarser ribs, a different outline, a special ornamentation or contrasting shell dimensions. They require no detailed discussion here. These are: seguenzae (GEMMELLARO 1871), the type species, juvavica (BITTNER 1890), haueri (BITTNER 1895), sp. I and sp. II RousSElle 1969, tubifera (STUR 1858), renevieri (HAAS 1884), blanci (HAAS 1884), anatolica (VADASZ 1913), pontica (MoIsSEeV 1934), yailaensis (MOISSEEV 1934).

The close morphological relationship between these species was already recognized by Mariani (1899). He concluded that S.? zitteli should be considered a group rather than a species name. Mihailovic (1955) also reported on the great inter- and infra-specific variability of Early Jurassic dimerelloids. Böse (1894) was confronted with this problem even earlier. He sug-

212 H. Sulser \& H. Furrer 
gested a new character in order to overcome the difficulties in specific determinations. This is a special shell ornament due to the intersections of concentric growth lines and the radiating ribs. The resulting network would depend on the periodicity of growth lines and the density of costellation, respectively. In Sulcirostra doesseggeri, such a pattern of network cannot be observed because concentric lines lack regular or rhythmic successions or are missing altogether. It is unclear whether in other cases this attempt to specify modifications in shell ornament is a suitable diagnostic element. In most instances, however, increments of shell growth depend to a great extent on environmental conditions. They may reflect certain time cycles and scarcely represent an inherent factor of a given species.

Several species were erected by Carapezza \& Schopen (1897) from Sicilian localities: Sulcirostra? insignis, reticulata, distefanoi, clathrata and others. They are mostly similar to either S.? zitteli, fuggeri and brusinai. With the information available, it is difficult to clarify the possible relationships between these species. During the late $19^{\text {th }}$ century, authors usually did not hesitate to erect new species on the grounds of minor variations in shape, which are often affected by external factors and life habits. In a detailed paper, Dubar (1938) dealt with several dimerelloid brachiopods from northern Africa. Unfortunately, the silicified material was of poor quality and the valves were mostly disarticulated and/or fragmentary. Through acid treatment, some details of the internal structures were established, but in general Dubar's paper could scarcely contribute new insights in the group as a whole.

Noteworthy is the endemism of these species. They are known from only a single or several localities, but always occur in isolated deposits (see also below, section Palaeoecology of the dimerelloid brachiopods). They accumulate in high abundance, but are usually poorly preserved, and qualifying descriptions were normally based on a small number of specimens. Therefore the selection of reliable characters for diagnostic purposes and determination work was somewhat arbitrary.

Externally Sulcirostra fuggeri is similar to Sulcirostra doesseggeri in overall shape, dimensions, outline, position of the umbo and the density of costellation. Frauscher (1883) counted 88 ribs at the edge of the ventral valve of the "best preserved specimen". As the ribs often bifurcate repeatedly, even in small specimens, this value depends on growth, but thus far largely agrees with the Engadine material. Sulcirostra fuggeri is in need of revision, but reference material is almost inexistent. Böse (1894) noted that in the original description by Frauscher (1883) most of the figured specimens were reconstructed or even composed of fragments of different specimens glued together. Böse figured only three intact measurable pieces. Today, only one poorly-preserved and complete shell (figured in Böse: Pl. 6, Fig. 3) along with a non-figured fragmentary piece remain. It is deposited in the "Bayerische Staatssammlung für Paläontologie" in Munich. Careful investigations of museum collections where part of the material was originally stored (Städtisches Carolino-Augusteum-Museum in Salzburg and Geologische Bundesanstalt in Vienna) were not successful in helping to locate further specimens. The type locality of Sulcirostra fuggeri is an erratic block of red limestone, allegedly from a Lowest Jurassic bed in the upper Brunntal on the northern slope of Untersberg near Salzburg, Austria. Collection of new material is not possible. We had the opportunity to inspect the only type specimen left and to section an incomplete fragment, where a fully recrystallized internal cast did not show any internal details. It thus did not make sense to try to assign the Engadine samples to the insufficiently known Sulcirostra fuggeri. As the Engadine forms show distinct and highly individualized internal characteristics, we decided to give them a new name: Sulcirostra doesseggeri $\mathrm{sp}$. nov.

The remaining costellate species mentioned above differ from Sulcirostra doesseggeri. In S.? hofmanni (Lowest Juras-

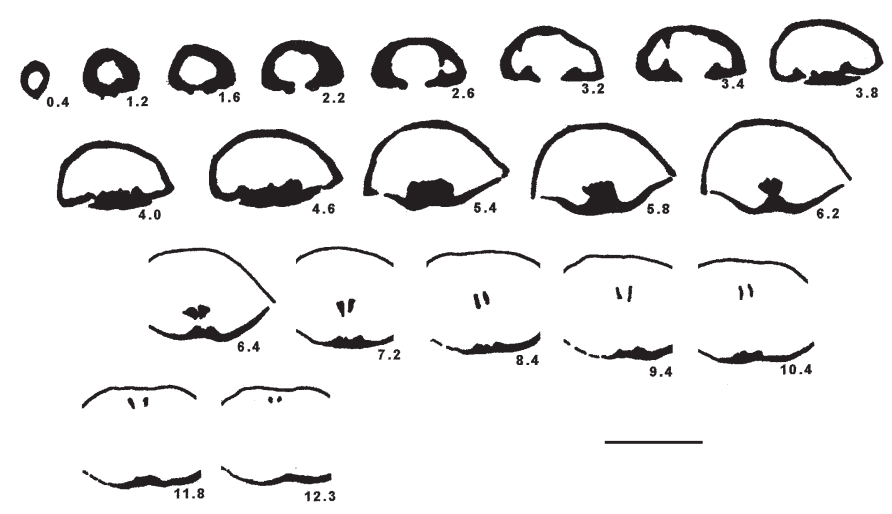

Fig. 10. Sulcirostra doesseggeri sp. nov. from Ils Fouruns (?lower Hettangian, Canton Graubünden, Switzerland). Series of transverse sections. Specimen of $21 \mathrm{~mm}$ length, $19 \mathrm{~mm}$ width, and $10 \mathrm{~mm}$ thickness (measurements are approximate due to the partly incomplete specimen) (PIMUZ 26 655). Scale bar: $1 \mathrm{~cm}$.

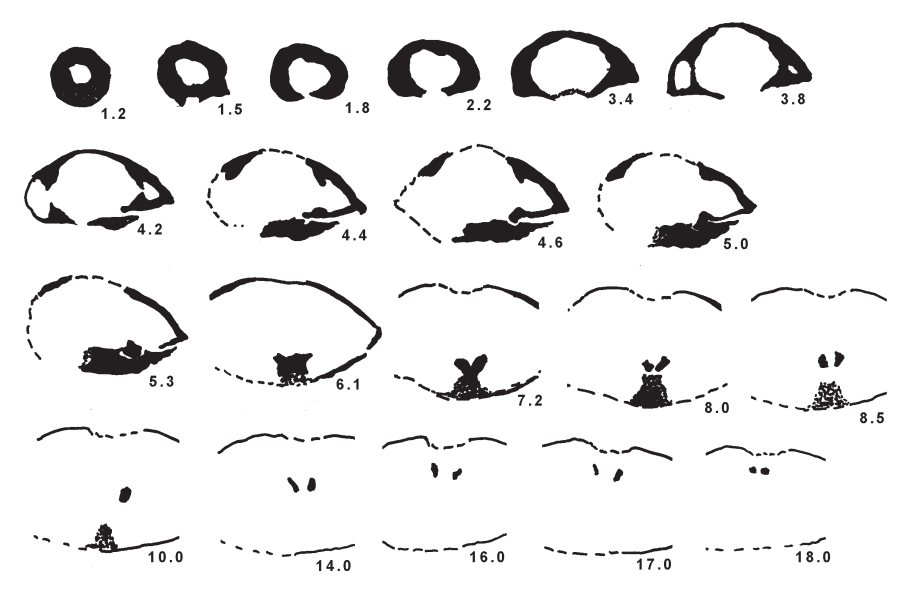

Fig. 11. Sulcirostra doesseggeri sp. nov. from Ils Fouruns (?lower Hettangian, Canton Graubünden, Switzerland). Series of transverse sections. Specimen of $24 \mathrm{~mm}$ length, $25 \mathrm{~mm}$ width, and $12 \mathrm{~mm}$ thickness (measurements are approximate due to the partly incomplete specimen) (PIMUZ 26 656). Scale bar: $1 \mathrm{~cm}$. 
sic of southern Bakony, Hungary) the outline is rounded and tear drop-like, but it has extremely fine and weak costellation, making the shell surface look almost smooth, similar to Rhynchonellina. Brachiopods from the Domerian of San Rocco di Adrara (Bergamo Province, Italy), which Parona (1884) erroneously described as $R$. hofmanni, were given a new name by Böse (1894): Rhynchonellina (now Sulcirostra) paronai. Cicardi \& Gaetani (1974) revised S. paronai and synonymized Parona's possibly gerontic individuals with that species. A narrow and arched hinge line and a flat sulcation on both valves are characteristic of S.? brusinai (Lower Jurassic of Smokovac near Risano in Dalmatia, Croatia). Eichenbaum (1883) described his species as having a dorsal median fold, but his figures show that this is incorrect. Böse (1894) later confirmed the bisulcate shell.

\section{Sulcirostra cf. zitteli (BöSE 1894)}

(Figs. 12, 13)

1894 Rhynchonellina Zitteli - Böse: 67-70, pl.7, Fig. 7-26 (?non 4-6), Textfig. 2d, 10-13

? 1916 Rhynchonellina Zitteli BÖSE - Frauenfelder: 321

? 1938 Rhynchonellina cf. Zitteli BösE - Dubar: 29, pl. 1, Fig. 12

1964 Rhynchonellina zitteli BÖSE - Alméras: 79

2002 Sulcirostra zitteli (BösE 1894) - Siblik: 15

Lectotype.-Sulcirostra zitteli (designated herewith). The specimen (AS XXVII 68) figured by Böse (1894: Pl. 7, Fig. 26), and
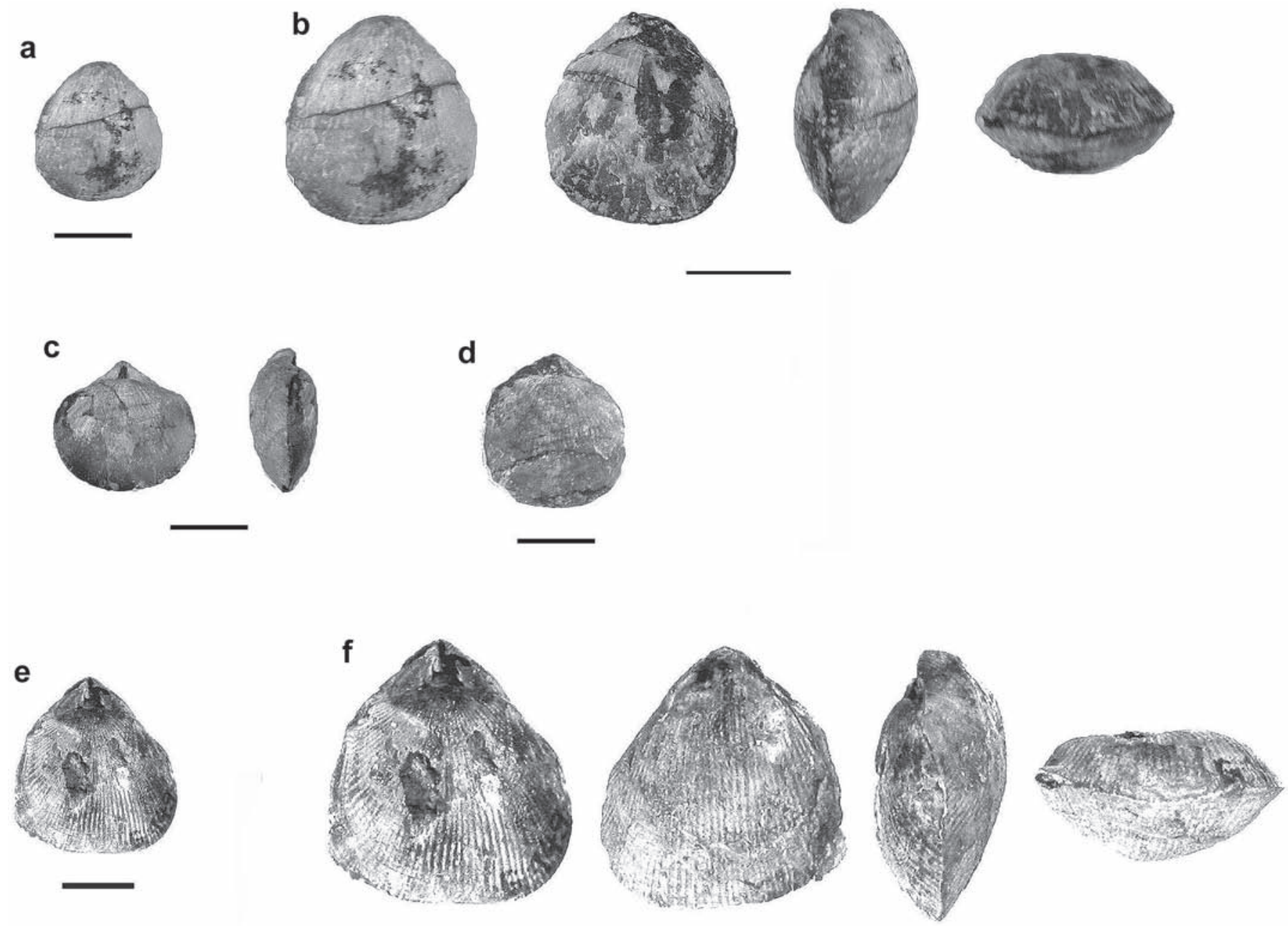

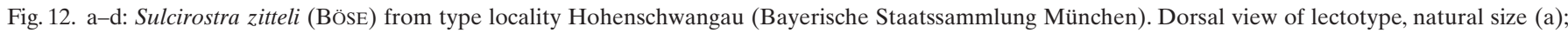

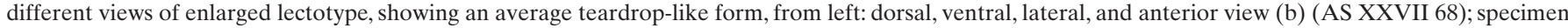

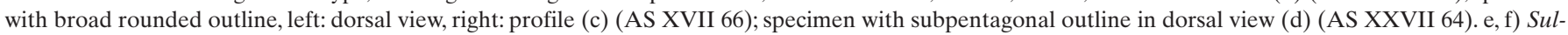

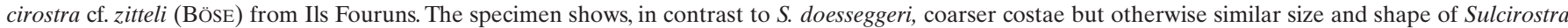

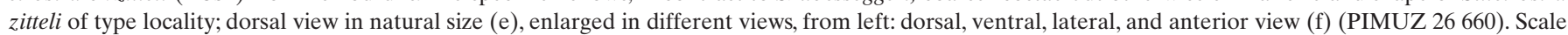
bars: $1 \mathrm{~cm}$.

214 H. Sulser \& H. Furrer 
refigured here in Figure 12a, b, from the Lowest Jurassic (in "Hierlatz" facies) near "Altes Schloss" in Hohenschwangau, Bavaria, Germany (Northern Calcareous Alps, Austroalpine nappes). Dimensions: $18.7 \mathrm{~mm}$ long, $16.7 \mathrm{~mm}$ wide, $10.3 \mathrm{~mm}$ thick.

Occurrence. - Type locality Hohenschwangau (Bavaria, Germany). Further localities not confirmed yet: Broccatello (Hierlatz-Kalk, Lowest Jurassic) of Melano, Southern Alps, Switzerland [the citation by Frauenfelder (1916) could not be confirmed, because no specimen was found in Frauenfelder's material in the collection of the Geological Institute at the Federal Institute of Technology, ETH Zurich]; Sinemurian (Turneri bed), Gorges du Foum Tillijt near Rich, High Atlas, Morocco (Dubar 1938).

Only one questionable specimen from the new locality Ils Fouruns, Canton Graubünden, Switzerland (see type locality Sulcirostra doesseggeri) is described below as Sulcirostra cf. zitteli.

Description. - (based on a single specimen PIMUZ 26 660).

External morphology (Figs. 12e, f). Shell length of $24 \mathrm{~mm}$, $22 \mathrm{~mm}$ width, and $12 \mathrm{~mm}$ thickness. Shell surface covered with regular, relatively coarser, radiating, partly branching ribs (12 on $10 \mathrm{~mm}$ of width at the front). All other characters such as size, profile, commissure, sulcation of dorsal valve, hinge line, umbo, interarea, delthyrium, and apical angle are comparable with those described for Sulcirostra doesseggeri.

Internal morphology. Not studied due to lack of material.

Discussion. - Among the material assigned to Sulcirostra doesseggeri there is a single specimen that is different due to its fewer ribs. It is best compared with Sulcirostra zitteli. Böse (1894) based the description of his species on a population of some 100 specimens. Despite variation, he was convinced he was dealing with only a single species. We thus chose an average specimen as lectotype. Two other specimens show the range of outlines (Figs. 12c, d).

Böse (1894) gave only a rough indication as far as costellation is concerned: $30-40$ ribs on larger and 15-20 ribs on smaller shells. We had the chance to check the rib density of the all topotype material housed in the Bayerische Staatssammlung in Munich. Near the anterior margin we counted 12 to 16 costae on $10 \mathrm{~mm}$ width, which is in accordance with the Engadine Sulcirostra zitteli. It is therefore clearly distinguished from S. doesseggeri, in which the number of ribs varies within 20 to 26 costae on $10 \mathrm{~mm}$. Bifurcation and intercalation of the costellae is less frequent than in S. doesseggeri. Since the internal structure of the single Engadine sample remains unknown and a direct comparison with $S$. zitteli of the type locality (Fig. 13) is not possible, we prefer to use an open nomenclature: Sulcirostra cf. zitteli. The generic attribution to Sulcirostra is based on the same arguments as discussed above.

Whereas Böse (1894) named similar brachiopods from Dalmatia S. zitteli, Bittner (1895) proposed the new species Rhynchonellina gemmellaroi. In this species, both valves lack either
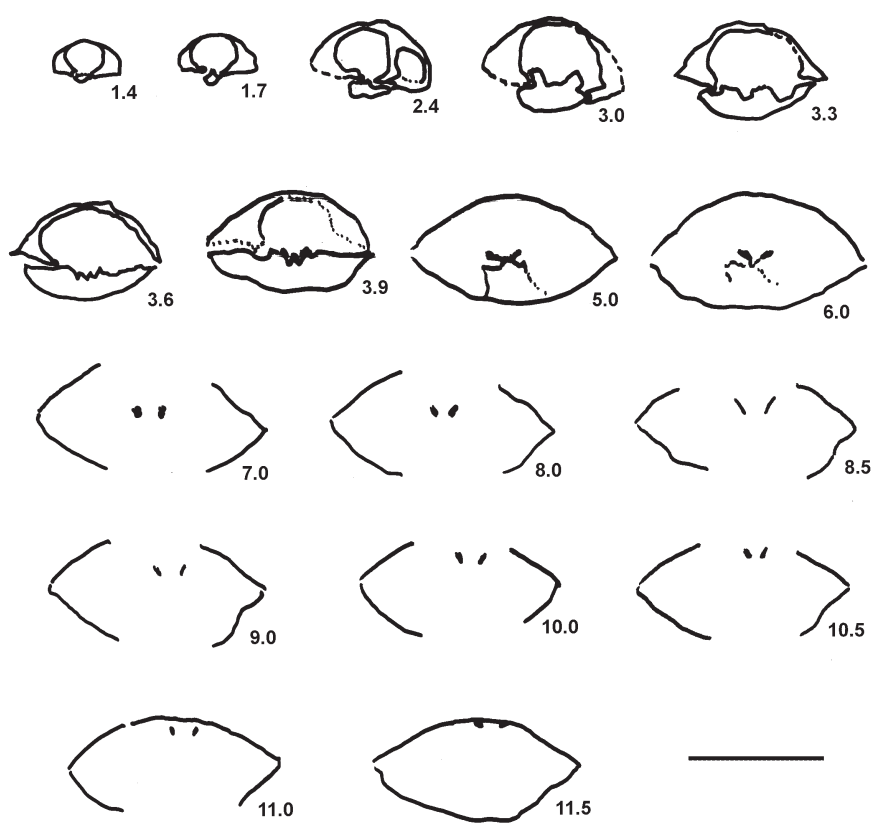

Fig. 13. Sulcirostra zitteli (BÖSE) from the type locality Hohenschwangau (PIMUZ 26 661). Series of transverse sections. Specimen of $17.2 \mathrm{~mm}$ length, $17.1 \mathrm{~mm}$ width, and $9.0 \mathrm{~mm}$ thickness. The internal morphology is similar that of $S$. doesseggeri. A pair of crura proximally attached to the base become free, turn parallel and extend over half shell length, approaching the ventral valve and ultimately almost touching it. This structure is typical for dimerelloid brachiopods. Scale bar: $1 \mathrm{~cm}$.

a median depression or elevation and their anterior margin is always rectimarginate. Rhynchonellina gemmellaroi may possibly be a synonym of $S$. zitteli, representing a morph within that species. Further species which show close affinities to $S$. zitteli are: Rhynchonellina orthisiformis BÖSE 1894 (nom. nov. for Spirifer orthiformis LEPSIUS 1878) and R. rothpletzi BÖSE 1894 (nom. nov. for $R$. orthisiformis ROTHPLETZ 1886). Descriptions of these species were based on only two incomplete and one single specimen, respectively.

Family uncertain

Genus Carapezzia TOMLIN 1930, nom. nov. for Geyeria CARAPEZZA \& SCHOPEN 1897

Type species Rhynchonellina (Geyeria) globosa CARAPEZZA \& SCHOPEN 1897

\section{Carapezzia engadinensis sp. nov.}

(Figs. 14-20)

1906 "Terebratula cf. Gerstenensis"-Zoeppritz: 193

1993 Rhynchonellina suessi BösE - Furrer: 80

Derivation of name.-engadinensis, referring to the occurrence in the Engadine valley.

Type locality. - Ils Fouruns (eastern glacial cirque, coordinates on Swiss topographic maps: 801.300/162.900), Swiss National Park near S-chanf, Canton Graubünden, Switzerland. Alpisella 
beds of the Allgäu Formation (?lower Hettangian); Ortler nappe (Austroalpine nappes).

Holotype. - PIMUZ 26662 (Figs. 14a, b). Dimensions: 28.5 mm long, $25.7 \mathrm{~mm}$ wide, $18.0 \mathrm{~mm}$ thick.

Occurrence. - Type locality.

Diagnosis. - Shell markedly biconvex, smooth or very feebly capillate; outline semi-circular to oval; umbo massive, suberect; low median septum in connection with a septalium; mergiform crura proximally fused, then closely parallel, extending half shell length.

Description. - In view of the fact that well preserved specimens are rare, an exhaustive description was not possible. The length varies from $28 \mathrm{~mm}$ (lectotype) to $68 \mathrm{~mm}$ (Fig. 16).

External morphology (Figs. 14-17). Profile markedly biconvex, dorsal valve near hinge line very inflated, often forming a swelling; maximum thickness in posterior part of the shell; valves meet smoothly at the lateral commissure; commissure practically straight. Outline semi-circular, oval or tear droplike. Shell surface normally smooth, but very fine capillate when perfectly preserved (Fig. 15d). Growth lines irregular, inconspicuous. Both valves lack sulcus or fold. Anterior commissure rectimarginate. Muscle fields not observed. Umbo high, massive, pointed, suberect to erect, with sharp ridges (Fig. 15b). Interarea high, delthyrium wide, triangular, partially closed by deltidial plates (Fig. 15c). Apical angle 80-90 .

Internal morphology (Figs. 18-20). Ventral valve: Occasionally filled with callose material. Dental plates absent. Hinge teeth massive, with denticular apophyses, well inserted in large round sockets. Dorsal valve: Median septum sharp, not persistent, short, distally becoming broad and very low. Median septum continuous with septalium. Hinge plates not defined. A pair of mergiform crura originates from the prolongation of the septalial plate and loose connection with the median septum at an early stage; crura remain fused proximally, forming a $\mathrm{Y}$ and finally a $\mathrm{V}$, covered by a fine structure of unknown nature. Dorsally the crura bend parallel, still connected by a very fine vertical lamella, extending more than half the shell length.
Discussion. - The long mergiform crura are the most important diagnostic character for attributing these smooth brachiopods to the Dimerelloidea. The genus Rhynchonellina, closely related to Sulcirostra, was first considered a reference for the smooth Engadine forms. But only R. suessi GEMMELLARO 1871 is somewhat similar in its subcircular or ovoid outline, and even more so in its inflated subspecies $R$. s. orobica, described by Cicardi \& Gaetani (1974). However, a comparison with $R$. suessi is not convincing.

The large, strongly globose, massive shell, and the high and pointed, very incurved umbo, which are typical features of the Engadine forms, are also seen in Carapezzia. This genus was now (Manceñido et al. 2002: vol. 4, p. 1238, Figs. 845a-n) separated from species related to Rhynchonellina, where it was originally grouped (Ager 1965b: H602-H603). Until now, it contained two species only: C. geyeri (BITTNER 1898) and C. globosa (CARAPEZZA \& SCHOPEN 1897). Knowledge of its internal structure was based on Bittner's pioneering sections of $C$. geyeri alone, whereas the internals of $C$. globosa are still unknown. Adult specimens of $C$. globosa grew into an almost perfect sphere in which the very curved umbo completely hides the delthyrial area. Ager et al. (1978) argued that in the assemblages of both the Sicilian C. globosa and the Austroalpine C. geyeri, specimens of varying size and shape might coexist and that there is no clear dividing line between the two species. Thus a large C. globosa might be a fully developed C.geyeri under conditions of maximal growth, and vice versa. Due to the lack of relevant specimens a distinct comparison of both species was not possible.

A further point of discussion is the stratigraphic range of the taxon. Although C. globosa, following the original description from the type locality Cappelluzza della Madonna near Bisacquino (Palermo, Sicily), was thought to be from the Early Jurassic, the Late Triassic cannot be excluded (Ager et al.1978). C. geyeri, considered by Bittner (1898) as a Rhaetian brachiopod, may be Early Jurassic as suggested by Schlager (1963). The type locality of C. geyeri (for the lectotype see Siblik 1988: 61, Pl. 4, Fig. 5) is in the Gailtal Alps in Carinthia (Austria), a
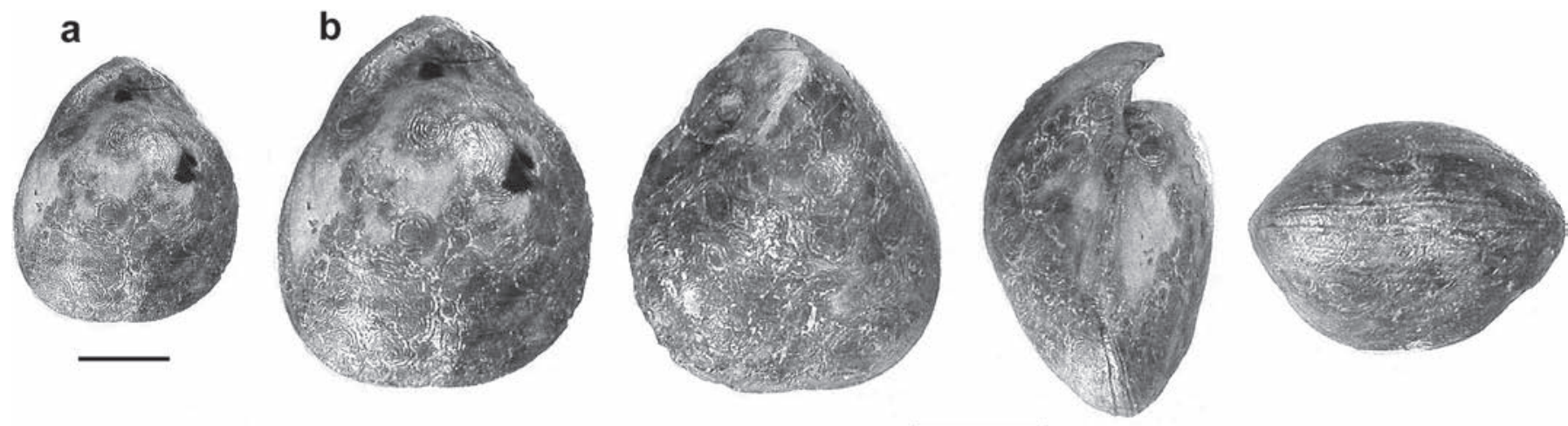

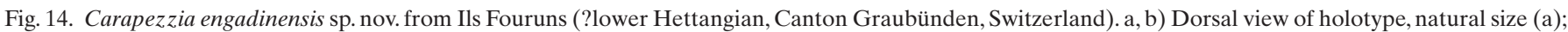
enlarged in different views, from left: dorsal, ventral, lateral, and anterior view (b) (PIMUZ 26 662). Scale bars: $1 \mathrm{~cm}$.

216 H. Sulser \& H. Furrer 


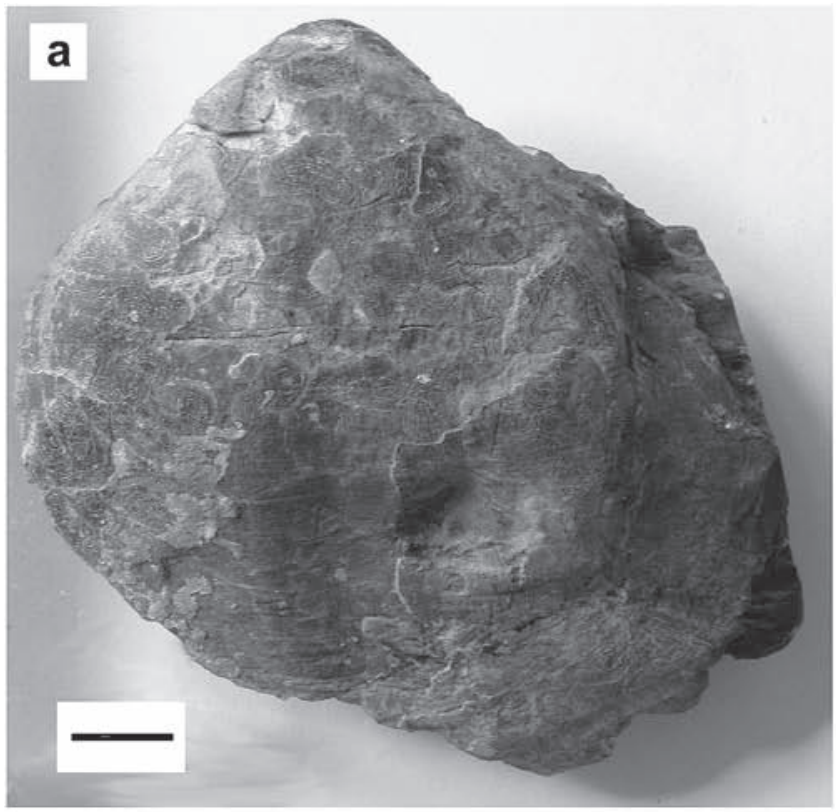

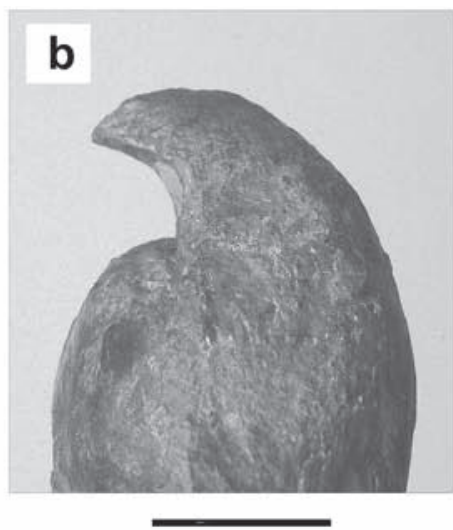



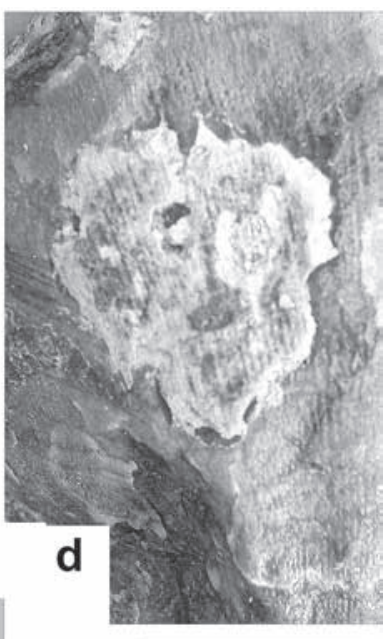

Fig. 15. Carapezzia engadinensis sp. nov. from Ils Fouruns (?lower Hettangian, Canton Graubünden, Switzerland). a) Ventral valve of a large, stout specimen, with circular outline (PIMUZ 26 663). b-d: Average specimen with marked beak in profile (b); showing the large, open delthyrium with traces of deltidial plates in dorsal view (c) (PIMUZ 26 664); preserved shell and internal cast of the ventral valve display a delicate ornament of fine capillae (d) (PIMUZ 26 664). Scale bars: $1 \mathrm{~cm}$.
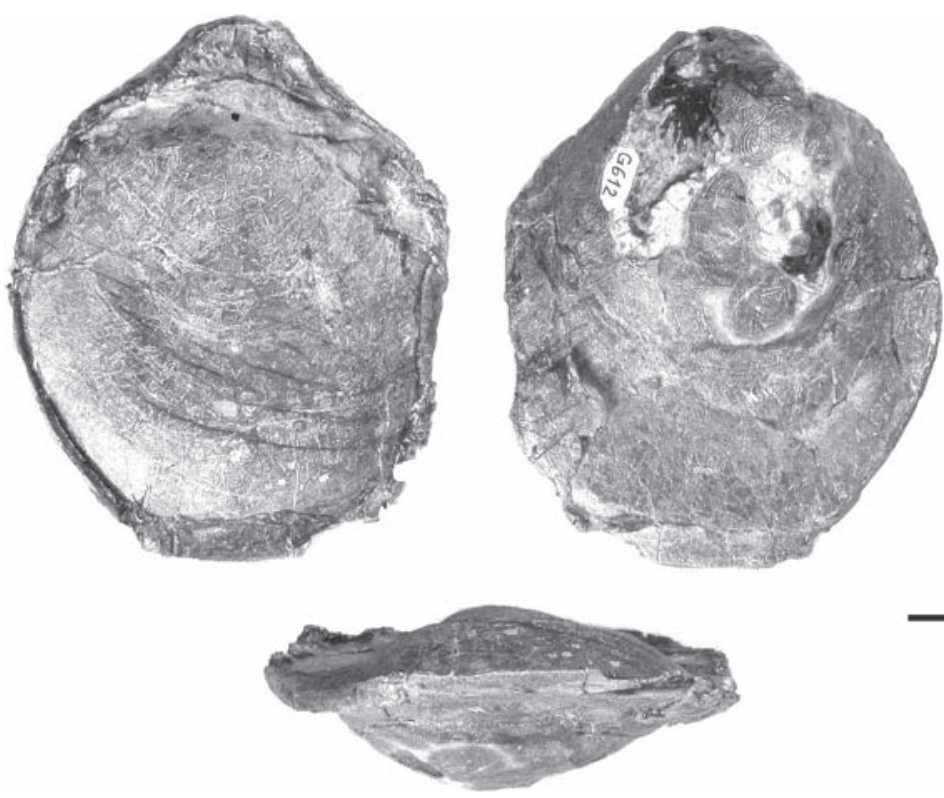

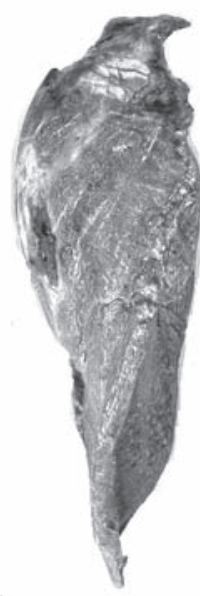

Fig. 16. Carapezzia engadinensis sp. nov. from Ils Fouruns (?lower Hettangian, Canton Graubünden, Switzerland). The largest specimen of the collection, it was completely compressed during fossilization and the shell partly crushed, from left: dorsal, ventral, and lateral view, below anterior view (PIMUZ 26 666). Scale bar: $1 \mathrm{~cm}$. 
tectonic unit with close affinities to the Austroalpine Northern Calcareous Alps. Additional but as yet unconfirmed occurrences are in the Crimea (Borisjak 1909), Northern Africa (Dubar 1938) and the Taurus Mountains of southern Turkey (Ager et al. 1978).

Regarding the external morphology of C. geyeri and C. engadinensis, both species have a very incurved umbo. In several specimens a very inflated dorsal valve with a swelling near the hinge line is present in both species so that the dorsal curvature becomes irregular. Furthermore, both species show certain accumulations of callose material, but only in $C$. geyeri it is so pronounced that the internal casts occasionally appear as odd shapes (e.g. the apical region in Bittner 1898: Pl. 12, Fig. 5 right, or the simulated (false) ventral fold in Fig. 5 left). The range of size variation is similar in both species. However, whereas in $C$. geyeri the relative width diminishes almost linearly with increasing length, $C$. engadinensis shows a less constant length/width relationship in the larger specimen (Fig. 17).

We had the opportunity to section a specimen of Carapezzia geyeri (BITTNER) from the topotype material of Bittner's collection, housed in the Geologische Bundesanstalt in Vienna. A structure of particular interest for specific assignment is the pair of crura. As seen in transverse sections they are fused proximally to form a Y, distally turning to a V. Before ultimately becoming separated from each other, they are connected by a very fine vertical lamella at their base. This connective band can be detected in Bittner's original sections (not commented upon), as well as in our sections of C. geyeri (Fig. 21, i.e. 7.7) and C. engadinensis (Fig. 18, 6.6 and 8.3-13.0; Fig. 19, 7.5-11.0). In Rhynchonellina suessi suessi and in $R$. s. orobica the crura are always separated, as was shown by the serial sections of Lombardian specimens published by Cicardi \& Gaetani (1974). In $C$. geyeri the crura appear as a Y-shape which is typically still supported by the median septum. By contrast, in C. engadinensis a septalial plate is connected with the median septum to form a septalium. In successive sections, this connection is disrupted before the Y-formed crura appear (Fig. 18, section 6.0 and following; Fig. 19, section 5.5 and following). This difference was thought to be species-relevant. In the distal sections, the final V-form in both $C$. geyeri and C. engadinensis is similar. None of the species of Carapezzia shows distinctive hinge plates. However, in C. engadinensis the open space above the Y-formed crura is covered by a roof-like structure (Fig. 18, sections 6.0-7.6; Fig. 19, sections 5.5-8.5). It looks as if this structural element of unknown function is weakly connected to the crura.

There are clearly distinguishable features of the Engadine specimens which we think justify the erection of a new species, well separated from $C$. geyeri. As long as the internal structures of the type species C. globosa are unknown, common characters, such as the massif shell shape, the incurved umbo, and the long, mergiform crura, partially connected to each other are regarded as generic characters for Carapezzia.

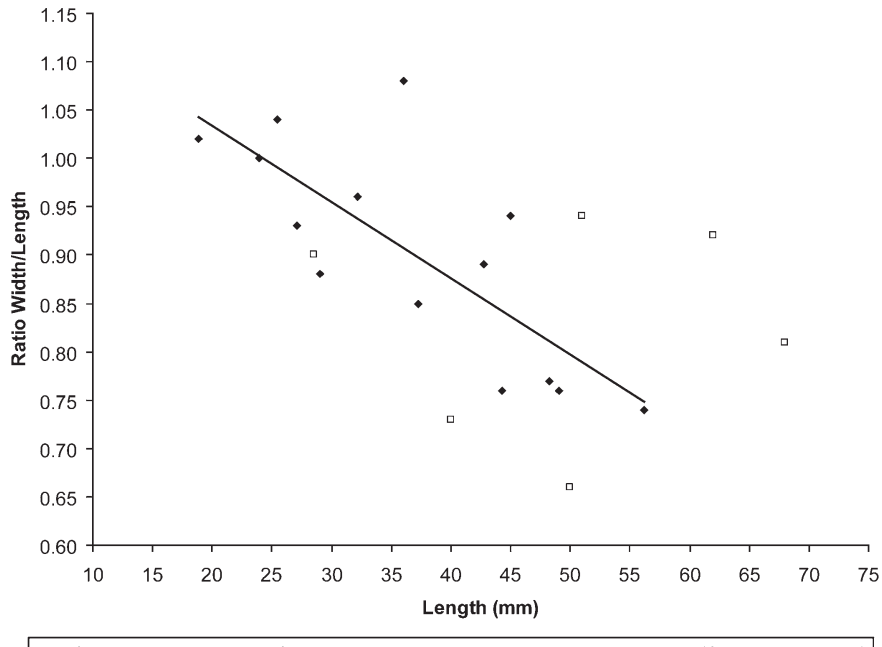

- Carapezzia geyeri ㅁ Carapezzia engadinensis nov. sp. — trend line (Carapezzia geyeri)

Fig. 17. Scatter diagram (width/length ratio vs. length) showing the variability of size and shape in Carapezzia engadinensis sp. nov. and Carapezzia geyeri (BITTNER).

\section{Classification aspects (H. Sulser)}

The superfamily Dimerelloidea ranges back to the Palaeozoic with the genera Dzieduszyckia SIEMIRADZKI (Upper Devonian) and Ibergirhynchia SANDY (Carboniferous). Evolutionary relationships among these and Mesozoic genera were proposed by Ager et al. (1972). External appearance seems to unite the Jurassic Rhynchonellina, Sulcirostra and Cooperrhynchia SANDY \& CAMPBELL 1994. In Manceñido et al. (2002: 1236-1238) they were combined in the subfamiliy Rhynchonellininae.

Sulcirostra, which originally was separated from Rhynchonellina simply on the grounds of its ribbed shell (Rhynchonellina s.s. is retained for the smooth dimerelloids), requires some comment. The most important diagnostic element in Sulcirostra is undoubtedly the extremely long crura that extend beyond half the shell length and are bent towards the ventral valve at their ends. This has been known since the end of the $19^{\text {th }}$ century when authors like Frauscher (1883), Böse (1894) and Bittner (1895) published longitudinal cuts along the mid-line. Detailed transverse serial sections, however, are rare, but in the few sectioned species parts of the cardinalia and the mode of articulation differ considerably. Thus, in Sulcirostra juvavica, lateral septa support small divided hinge plates from which the crura evolved. A septalium is not present and the median septum is very short (Ager 1959,1965b). Sulcirostra paronai displays a Rhynchonellina-like interior with large hinge plates, a cardinal process and dental lamellae, but lacking a median septum. The crura gradually bend until parallel. In S. alpina the crura seem to evolve directly from a pair of septa attached to the wall (Cicardi \& Gaetani 1974, Sulser \& Furrer 2005). S. doesseggeri and S. cf. zitteli, the costellate dimerelloids from the Engadine locality described

218 H. Sulser \& H. Furrer 
here, resemble the smaller $S$. alpina, but display a compact cardinalium, before it divides and gives rise to the crura. If more species presently attributed to Sulcirostra reveal the detailed organisation of their internal structure in the future, a reassessment of the genus and perhaps of new genera may become necessary.

The suprageneric classification of Carapezzia is problematic. In Manceñido et al. (2002: 1238) it is tentatively placed in the dimerelloid family Peregrinellidae as the only smooth form among the coarsely costate genera ranging from Upper Devonian to Lower Cretaceous, including the type genus Peregrinella OEHLERT 1887. Carapezzia shares important features with Peregrinella: long, parallel, mergiform crura, fused and fixed at their origin by a median septum (Trümpy 1956). It is, however, difficult to reconcile these internal similarities with the smooth Carapezzia on the one hand and the strongly costate Peregrinella on the other. With preference to derive the latter from a probably direct Palaeozoic ancestor, Carapezzia might be better placed within the Rhynchonellinines (see Ager 1965b: H603). When more relevant data on Carapezzia are available, a more precise definition of the genus may emphasize the "merged" form of crura (like in Peregrinella) as a key diagnostic feature, whereas the crural "support" by a septum (like in C. geyeri) or by a septalium (like in C. engadinensis) may alternate. In this regard, Carapezzia would again move to a position closer to Peregrinella. For the time being we prefer to restrict the classification to the superfamilial level (Dimerelloidea), leaving the familial assignment open.

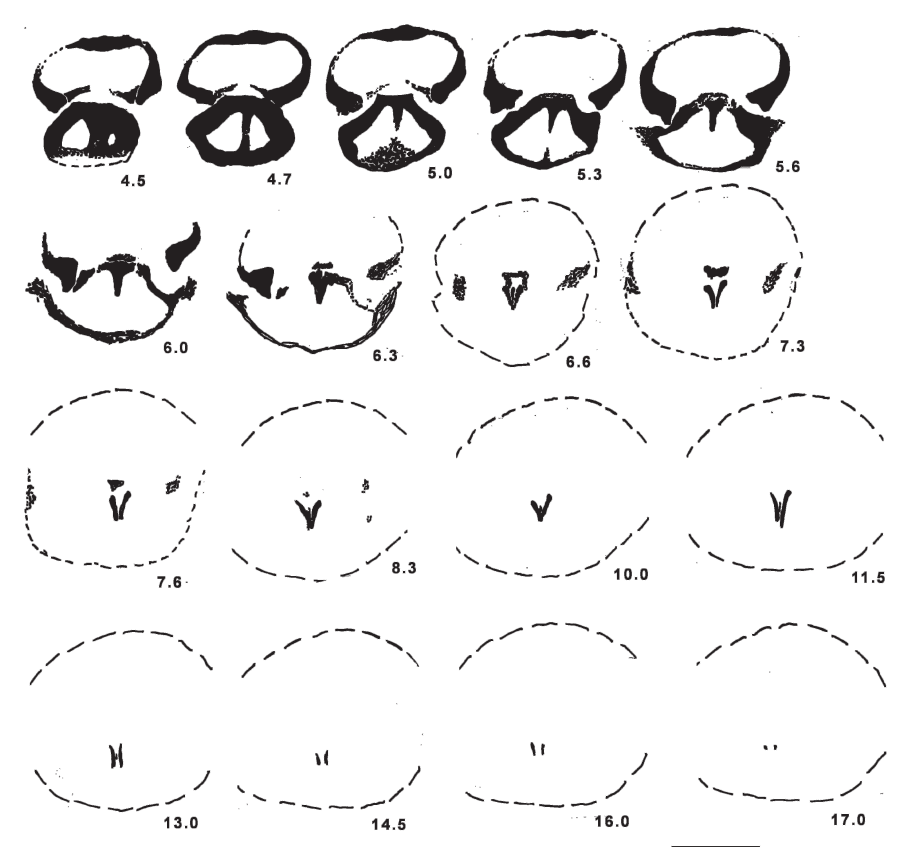

Fig. 18. Carapezzia engadinensis sp. nov. from Ils Fouruns (?lower Hettangian, Canton Graubünden, Switzerland). Series of transverse sections. Specimen of $40 \mathrm{~mm}$ length, $29 \mathrm{~mm}$ width, and $22 \mathrm{~mm}$ thickness (measurements are approximate due to the partly incomplete specimen) (PIMUZ 26 667). Scale bar: $1 \mathrm{~cm}$.

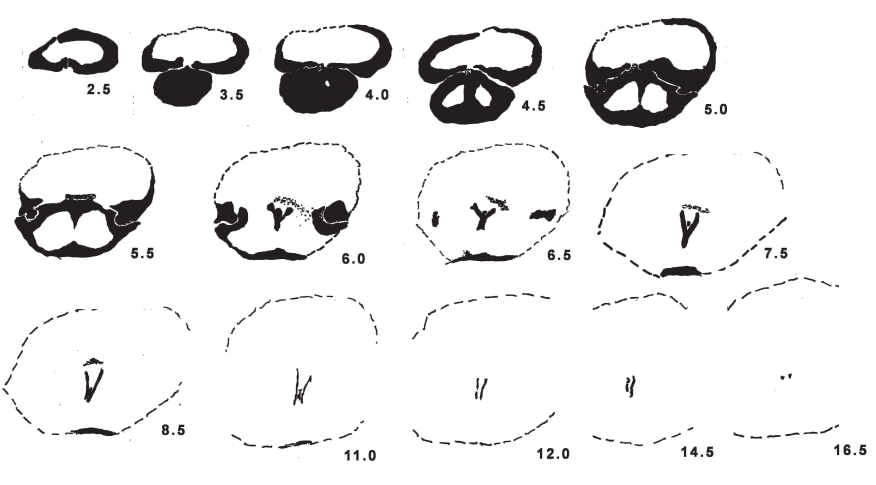

Fig. 19. Carapezzia engadinensis sp. nov. from Ils Fouruns (?lower Hettangian, Canton Graubünden, Switzerland). Series of transverse sections. Specimen of $50 \mathrm{~mm}$ length, $33 \mathrm{~mm}$ width, and $21 \mathrm{~mm}$ thickness (measurements are approximate due to the partly incomplete specimen) (PIMUZ 26 668). Scale bar: $1 \mathrm{~cm}$

\section{Palaeoecology of the dimerelloid brachiopods \\ (H. Furrer and H. Sulser)}

All the dimerelloid brachiopods, described in this paper, were recovered from three localities on the same mountain crest, about one km north-west of Piz Chaschauna, and lie within the Alpisella beds at the base of the Allgäu Formation. Although no index fossils have been found at the three localities, the stratigraphic correlation of the Alpisella beds indicate an early Hettangian age for the fauna. The fossiliferous beds are nearly monospecific accumulations in a turbiditic sequence, with most shells broken or deformed by early diagenetic compaction and Alpine tectonics. The turbiditic sequence seems to form a local fan-like deposition just above a mass flow breccia (Chaschauna megabreccia). Megabreccia and turbidites are in contact with the footwall of an Early Jurassic fault scarp and overlain by the younger Trupchun beds (Sinemurian-Pliensbachian). The Trupchun beds also display fine grained turbidites, local olistoliths, and megabreccias, interpreted as hemipelagic sediments in a deeper basin formed during an early rifting phase of the Jurassic Tethys ocean (Froitzheim \& Eberli 1990). The large blocks and the smaller clasts of the olistoliths, megabreccias and conglomerates in the turbiditic sequence are usually typical lithologies from the Upper Triassic Kössen Formation; components from the even older Norian Hauptdolomite are rare. These shallow water carbonates must have been eroded during and after block faulting and transported by gravitational sliding into the basin. The remaining horst structures formed submarine highs, which were possibly hard grounds for benthic organisms. The existence of such a submarine high has been proven by the only occurrence of Sulcirostra alpina, found in a re-sedimented block, together with several clasts of crinoidal limestone (Hierlatz limestone) in another exposure of the Chaschauna megabreccia at the base of the Allgäu Formation (Furrer 1993, Sulser \& Furrer 2005). Most faunal elements found together with the dimerelloid brachiopods are allochthonous epibenthic organisms (crinoids, bivalves, siliceous 
sponges), originally attached to the hard ground of a submarine high. They were transported by turbidity currents into an abiotic environment in a deeper part of the basin.

According to the literature, nearly all localities with dimerelloid brachiopods of Early Jurassic age occur in very limited areas. This concerns the species of Rhynchonellina, Sulcirostra and Carapezzia. Furthermore, they occur in mono- or oligospecific populations and commonly with the exclusion of associated fossils. Known localities of this kind occur in southern Europe, Turkey and northern Africa. Representatives of the Early to Middle Jurassic dimerelloids Anarhynchia (Ager 1968) or the Late Jurassic Cooperrhynchia (Sandy \& Campbell 1994) have only been recorded from single sites in California. It is also remarkable that a similar discontinuous and punctuated distribution has been reported from Peregrinella, a dimerelloid genus of Early Cretaceous age (Ager 1986). Ager (1965a) suggested that Peregrinella was adapted for shallow, high-energy sea-floors with little possibility to accumulate in such an environment. In exceptional cases they were saved from complete destruction by accidental transportation into deeper water. Transport is also indicated for the Early Jurassic dimerelloids Sulcirostra and Carapezzia described here from the Engadine locality. The associated fauna, rich in siliceous sponges, crinoids and epibenthic bivalves, in addition to the sedimentary facies with megabreccias and turbidites suggest current dominated hardgrounds on submarine highs and deposition along steep fault scarps. Shells and other skeletal elements of dead organisms were transported into neighbouring basins together with
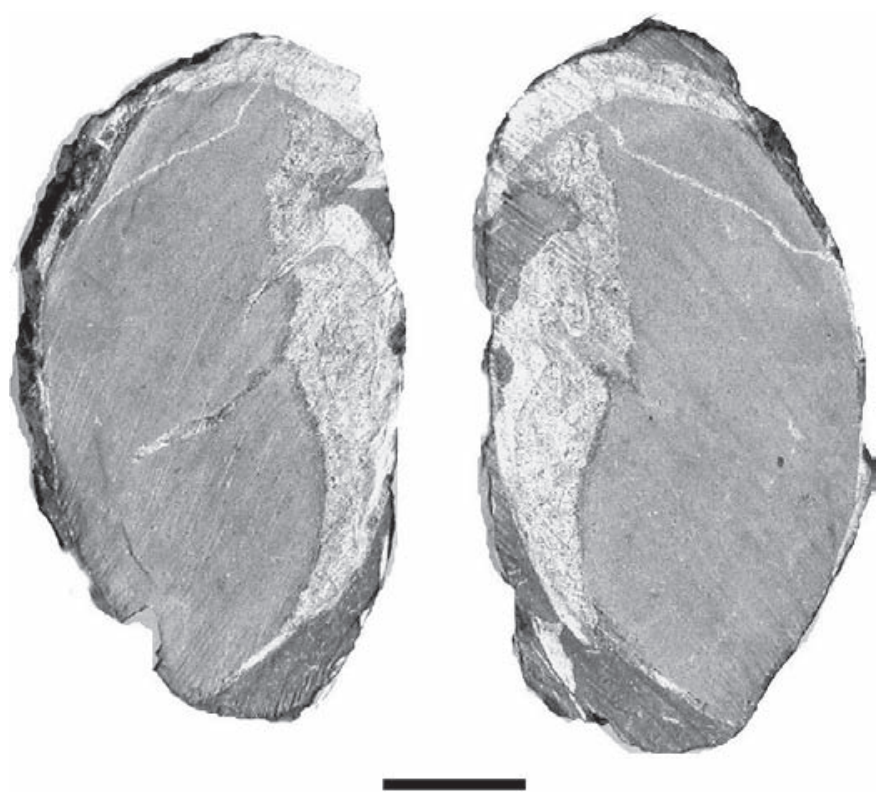

Fig. 20. Carapezzia engadinensis sp. nov. from Ils Fouruns (?lower Hettangian, Canton Graubünden, Switzerland). Shell cut in two halves along the median line. Left: full length of one of the crura is visible (the other crus was cut off). The broad white area that covers much of the inside of the dorsal valve (seen in both halves) represents calcite cement (geopetal fabric) and does not represent a septum (PIMUZ 26 669). Scale bar: $1 \mathrm{~cm}$.
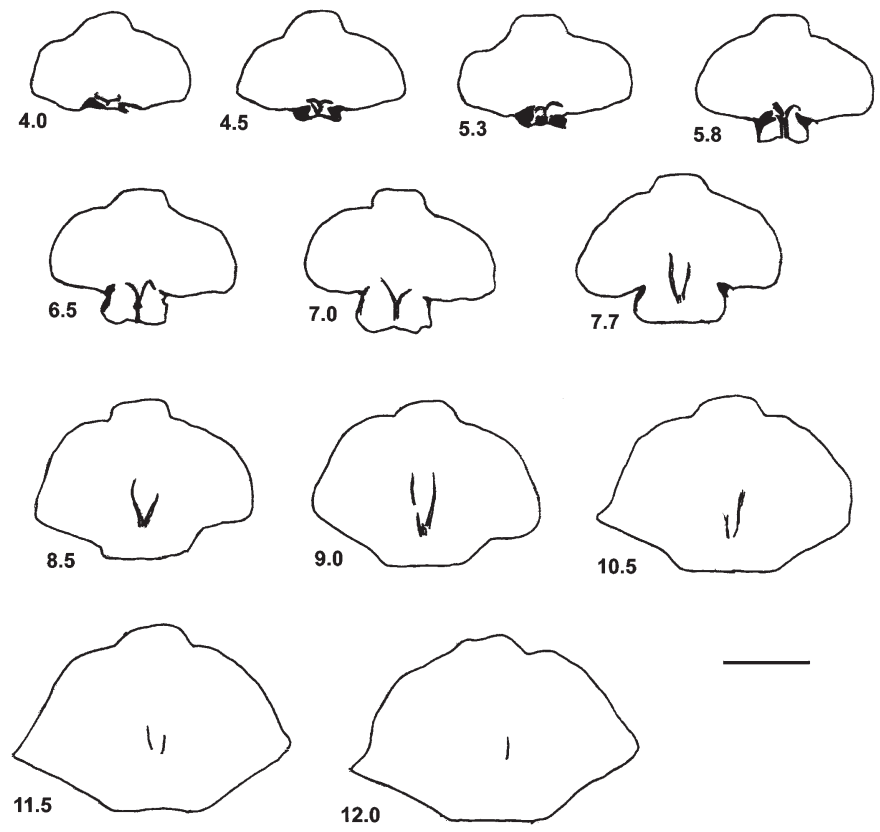

Fig. 21. Carapezzia geyeri (BITTNER). Series of transverse sections of a nonfigured syntype from Gailtal (Geologische Bundesanstalt Wien 1898/1/1/18) of $44 \mathrm{~mm}$ length, $43 \mathrm{~mm}$ width, and $26 \mathrm{~mm}$ thickness. The specimen was preserved as internal cast. The irregular outline of the sections points to the original fillings by callose material. Scale bar: $1 \mathrm{~cm}$.

loose sediment. The submarine highs must have been about $100 \mathrm{~m}$ below sea level or even deeper, because phototrophic organisms such as corals or algae are totally lacking. Similar environments with local submarine highs and basins are well known from other Jurassic localities in the circum-Mediterranean realm, especially at localities with dimerelloid brachiopods.

Another model for ecological interpretation of some dimerelloid brachiopods as local cold seep-associations was proposed for the Tithonian Cooperrhynchia by Sandy \& Campbell (1994), for the Cretaceous Peregrinella by Campbell \& Bottjer (1995a) and the Carboniferous Ibergirhynchia by Gischler et al. (2003). So the Early Jurassic dimerelloids Sulcirostra and Carapezzia could also have been adapted to hydrothermal vent and cold seep environments. Campbell \& Bottjer (1995a, b) suggested criteria to identify ancient cold seep environments: 1 ) stratigraphically restricted occurrences of vent-type taxa (typically worm tubes or molluscs with extant chemosymbiotic relatives); 2) enclosure within sedimentary precipitates derived from fluid seepage (e.g. sulphide-sulphate minerals, isotopically distinctive carbonates); and 3) incongruities between these isolated carbonates and surrounding strata (e.g. dense, fossil-rich, "reef-like" carbonate accumulations enclosed in fossil-poor, fine-grained siliciclastic strata; occurrence of aragonite cements in cold, deepsea palaeoenvironments). An additional criterion, a tectonic regime with the potential to generate anomalous fluids, is 
evident by the presence of contemporaneous normal faults in the Chaschauna-Trupchun area. However, the occurrence of the Engadine fauna as allochthonous elements in shell beds of turbidites and not in "reef-like" carbonate lenses contradicts this model. Other vent-type taxa such as tube worms or chemosymbiotic bivalves and sulphide-sulphate mineral deposits are also absent.

The dimerelloids within the rhynchonellides are related by the same general assembly of internal structures, primarily the extremely long crura. For "normal" rhynchonellids with typically short crura, it is suggested that only the proximal end of the lophophore was supported, and the distal end free for uncoiling. This kind of uncoiling of the spiral lophophore, i.e. the ability to extend the feeding organ beyond the shell, has been observed by various authors in only a few living rhynchonellids. Ager (1987) argued that such a capability was advantageous for suspension feeders, especially in conditions where food or oxygen supply became restricted. If this hypothesis is correct we can deduce that the dimerelloids, with their long crura, were handicapped by this more rigid framework in their feeding and/ or respiration capacity. So it is possible, that the dimerelloid brachiopods lived as specialised forms on current dominated hardgrounds with rich food and supplies of oxygen.

\section{Conclusions}

With the present paper the knowledge of the dimerelloid brachiopod, a distinct group within the rhynchonellids, is enlarged. This concerns species of the Lower Jurassic in the Austroalpine Ortler nappe of the eastern Swiss Alps (Engadine), namely Sulcirostra alpina, S. doesseggeri, S. cf. zitteli, and Carapezzia engadinensis. Sulcirostra alpina which since long was known to occur in the Southern Alps, was identified also in the Engadine by Sulser \& Furrer (2005). The other species of Sulcirostra and Carapezzia engadinensis seem to be restricted to the Early Jurassic of the Ortler nappe Engadine. The dimerelloids are still a difficult superfamily within the brachiopods which raises several taxonomical and palaeoecological problems. Thus, the genera Sulcirostra and Carapezzia both need clarifications with regard to their generotypes. Within the scope of the Engadine species which are described in this paper we discussed some of the relevant problems left for future research. The Engadine fauna does not support the model of dimerelloid brachiopods as local cold seep-associations. The brachiopod shells of the Ortler nappe were concentrated as allochthonous elements in Lower Jurassic turbidites and not in "reef-like" carbonate lenses.

\section{Acknowledgements}

In 1979 the Board of the Swiss National Park in Zernez gave special permission to study the area and to collect fossil material in the Val Trupchun. Rudolf Trümpy and Rudolf Dössegger (deceased in 2003) introduced one of the authors (H. Furrer) into the geology of the Engadine and called his attention to the fossil locality Ils Fouruns. Rare original material from the collections of A. Bittner, deposited at the Geologische Bundesanstalt in Vienna, was kindly made available for comparison by Dr. Irene Zorn and Dr. Harald Lobitzer.
One of the syntypes of Carapezzia geyeri was generously provided for sectioning purposes. Dr. M. Nose, Bayerische Staatssammlung in Munich, permitted an inspection of relevant brachiopod samples. Mark Eberhard made transverse sections of two specimens. Heinz Lanz (PIMUZ) and Urs Oberli (St. Gallen) prepared some brachiopods and Rosi Roth (PIMUZ) shot some photos. Rudolf Schlatter (Leipzig) determined the ammonites. Drawings were made by Andreas Baumeler (Zürich) and Carlo Romano (Zürich), sponsored by Max Kuhn (Uster). Scott Loren brushed up the English. We would like to thank the reviewers Neda Motchurova-Dekova and Rudolf Trümpy, but also the Associate Editor David A.T. Harper for the important improvement of the original manuscript.

\section{REFERENCES}

Ager, D.V.1959: The classification of the Mesozoic Rhynchonellida. Journal of Paleontology 33, 324-332.

Ager, D.V.1965a: The adaptation of Mesozoic brachiopods to different environments. Palaeogeography, Palaeoclimatology, Palaeoecology 1,143-172.

Ager, D.V. 1965b: Mesozoic and Cenozoic Rhynchonellacea. In: Moore, R.C. (Ed.): Treatise on Invertebrate Paleontology, Part H, Brachiopoda, vol. 2. The Geological Society of America and The University of Kansas, Boulder, H597-H632.

Ager, D.V. 1968: The supposedly ubiquitous Tethyan brachiopod Halorella and its relations. Journal of the Paleontological Society India 5-9 (for 1960-1964), 54-70.

Ager, D.V. 1986: Migrating fossils, moving plates and an expanding earth. Modern Geology 10, 377-390.

Ager, D.V.1987: Why the rhynchonellid brachiopods survived and the spiriferids did not: a suggestion. Palaeontology 30,853-857.

Ager, D.V., Childs, A. \& Pearson, D.A.B. 1972: The evolution of the Mesozoic Rhynchonellida. Geobios 5, 157-233.

Ager, D.V., Gutnic, M., Juteau, Th. \& Monod, O. 1978: New Early Mesozoic Brachiopods from Southern Turkey. Bulletin Mineral Research and Exploration Institute of Turkey 11, 59-75.

Alméras, Y. 1964: Brachiopodes du Lias et du Dogger. Essai bibliographique et critique de Paléontologie stratigraphique. Documents des Laboratoires de Géologie de la Faculté des Sciences de Lyon 5, 1-161.

Bittner, A. 1895: Ueber die Gattung Rhynchonellina Gemm. Jahrbuch der kaiserlich-königlichen geologischen Reichsanstalt 44 (1894), 547-572.

Bittner, A. 1898: Rhynchonellina Geyeri, ein neuer Brachiopode aus den Gailthaler Alpen. Jahrbuch der kaiserlich-königlichen geologischen Reichsanstalt 47, 387-392.

Böse, E. 1894: Monographie des Genus Rhynchonellina Gemm. Palaeontographica Stuttgart 41, 48-80.

Borisjak, A. 1909: Pseudomonotis ochotica Tell. Krymsko-kavkazskago triasa. Izvestija Geologitcheskago Komiteta 28, 87-102 (in Russian with German summary).

BWG (Bundesamt für Wasser und Geologie) (Ed.) 2005: Tektonische Karte der Schweiz $1: 500000$. Bern.

Campbell, K.A. \& Bottjer, D.J. 1995a: Peregrinella: an Early Cretaceous coldseep-restricted brachiopod. Paleobiology 21, 461-478.

Campbell, K.A. and Bottjer, D.J. 1995b: Brachiopods and chemosymbiotic bivalves in Phanerozoic hydrothermal vent and cold seep environments. Geology 23, 321-324.

Carapezza, E. \& Schopen, L.F. 1897: Sopra alcune nuove rhynchonellinae della Sicilia. Giornale di Scienze Naturali ed Economiche di Palermo 21, 215-251 (published for 1896).

Caron, M., Dössegger, R., Steiger, R. \& Trümpy, R. 1982: Das Alter der jüngsten Sedimente der Ortler-Decke (Oberostalpin) in der Val Trupchun (Schweizerischer Nationalpark, Graubünden). Eclogae geologicae Helvetiae 75, 159-169.

Cicardi, G. \& Gaetani, M. 1974: Revisione delle Rhynchonellininae (Brachiopoda) del Liassico del Bacino Lombardo. Rivista Italiana Paleontologia 80, 351-388.

Conti, P., Manatschal, G. \& Pfister, M. 1994: Synrift sedimentation, Jurassic and Alpine tectonics in the central Ortler nappe (Eastern Alps, Italy). Eclogae geologicae Helvetiae 87, 63-90. 
Dössegger, R. 1987: Geologische Karte des Schweizerischen Nationalparks 1:50000. Schweizerische Geologische Kommission.

Dössegger, R., Furrer, H. \& Müller, W. 1982: Die Sedimentserien der Engadiner Dolomiten und ihre lithostratigraphische Gliederung. Teil II. Eclogae geologicae Helvetiae 75, 303-330.

Dubar, G. 1938: Brachiopodes rhnychonellines du Rif. Service des Mines et de la Carte Géologique, Notes et Mémoires Marocco, Mémoire Paléontologique 9, 1-52.

Eberli, G.P. 1987: Carbonate turbidite sequences deposited in rift-basins of the Jurassic Tethys Ocean (Eastern Alps, Switzerland). Sedimentology 34 363-388.

Eberli, G.P. 1988: The evolution of the southern continental margin of the Jurassic Tethys Ocean as recorded in the Allgäu Formation of the Austroalpine Nappes of Graubünden (Switzerland). Eclogae geologicae Helvetiae $81,175-214$.

Eichenbaum, J. 1883: Die Brachiopoden von Smokovac bei Risano in Dalmatien. Jahrbuch der kaiserlich-königlichen geologischen Reichsanstalt $33,713-720$.

Frauenfelder, A. 1916: Beiträge zur Geologie der Tessiner Kalkalpen. Eclogae geologicae Helvetiae 14, 247-367.

Frauscher, K. 1883: Die Brachiopoden des Untersberges bei Salzburg. Jahrbuch der kaiserlich-königlichen geologischen Reichsanstalt 33, 721734.

Froitzheim, N. 1988: Synsedimentary and synorogenic normal faults within a thrust sheet of the Eastern Alps (Ortler zone, Graubünden, Switzerland). Eclogae geologicae Helvetiae 81, 593-610.

Froitzheim, N. \& Eberli, G.P. 1990: Extensional detachment faulting in the evolution of a Tethys passive continental margin, Eastern Alps, Switzerland. Geological Society of America Bulletin 102, 1297-1308.

Froitzheim, N., Schmid, S.M. \& Conti, P. 1994: Repeated change from crustal shortening to orogen-parallel extension in the Austroalpine units of Graubünden. Eclogae geologicae Helvetiae 87, 559-612.

Furrer, H. (Ed.) 1985: Field workshop on Triassic and Jurassic sediments in the Eastern Alps of Switzerland. Mitteilungen Geologisches Institut ETH und Universität Zürich (N.F.) 248, 81 pp.

Furrer, H. 1993: Stratigraphie und Facies der Trias/Jura-Grenzschichten in den oberostalpinen Decken Graubündens. Dissertation Universität Zürich, $112 \mathrm{pp}$.

Gischler, E., Sandy, M.R. \& Peckmann, J. 2003: Ibergirhynchia contraria (F.A. Roemer, 1850), an Early Carboniferous seep-related rhynchonellide brachiopod from the Harz mountains, Germany - A possible successor to Dzieduszyckia? Journal of Paleontology 77,293-303.

Manceñido, M.O., Owen, E.F., Savage, N.M. \& Dagys, A.S. 2002: Dimerelloidea. In: Kaesler, R.L. (Ed.): Treatise on Invertebrate Paleontology, Part H, Brachiopoda, revised, vol. 4: Rhynchonelliformea (part). The Geological Society of America and The University of Kansas, Boulder, 1236-1245.
Mariani, E. 1899: Sul calcare marnoso puddingoide pseudo-giurese di Biandronno e su una Rhynchonellina del Lias inferiore dell'alta Brianza. Rendiconti Reale Istituto Lombardo Scienze Lettera 32, 726-732.

Mihailovic, M. 1955: Quelques espèces de Rhynchonellinae du calcaire Jurassique à Smokovac près de Risan (Boka Kotorska). Annales Géologiques de la Péninsula balkanique 23, 67-73 (in Serbian with French summary).

Parona, C.F. 1884: Sopra alcuni fossili del Lias inferiore di Carenno, Nese e Adrara nelle Prealpi Bergamasche. Atti Societa italiana Scienze naturale Milano 37, 356-367.

Sandy, M.R. and Campbell, K.A. 1994: New rhynchonellid brachiopod genus from Tithonian (Upper Jurassic) cold seep deposits of California and its paleoenvironmental setting. Journal of Paleontology 68, 1243-1252.

Schlager, W. 1963: Zur Geologie der östlichen Lienzer Dolomiten. Mitteilungen der Gesellschaft der Geologie- und Bergbaustudenten in Österreich $13,41-120$

Siblik, M. 1988: Catalogus fossilium Austriae. Heft Vc 2 (a): Brachiopoda mesozoica. a) Brachiopoda triadica. Österreichische Akademie der Wissenschaften Wien, 131 pp.

Siblik, M. 2002: Liassic Bachiopods of the Northern Calcareous Alps and their generic attributions. Österreichische Akademie der Wissenschaften Mathematisch-naturwissenschaftliche Klasse, Anzeiger Abteilung I Biologische Wissenschaften und Erdwissenschaften 136 (for 2001), 3-17.

Sieber, N. 1965: Geologie des Gebietes zwischen Val Trupchun und Val Casanna. Unpublished Diplomarbeit ETH Zürich.

Sulser, H. \& Furrer, H. 2005: Die Brachiopoden des südalpinen Lias von Arzo (Kt. Tessin, Schweiz) - Taxonomie und Stratigraphie. Geologia Insubrica 8, 3-52.

Trümpy, R. 1956: Notizen zur mesozoischen Fauna der innerschweizerischen Klippen. I. Die unterliasischen exotischen Blöcke bei Iberg. II. Peregrinella aus der Unterkreide der Musenalp. Eclogae geologicae Helvetiae 49, 573-591.

Trümpy, R. 1980: Geology of Switzerland. Part B: Geological Excursions. Wepf \& Co, Basel, 334 pp.

Trümpy, R., Schmid, S.M., Conti, P. \& Froitzheim, N. 1997: Erläuterung zur Geologischen Karte des Schweizerischen Nationalparks 1:50000 (Geologische Spezialkarte 122). Nationalpark-Forschung in der Schweiz 87, $35 \mathrm{pp}$.

Zoeppritz, K. 1906: Geologische Untersuchungen im Oberengadin zwischen Albulapass und Livigno. Berichte der naturforschenden Gesellschaft Freiburg i.Br. 16, 164-231.

Manuscript received February 26, 2007

Revision accepted January 23, 2008

Published Online first March 24, 2008

Editorial handling: D.A.T. Harper \& J.-P. Billon-Bruyat 